\title{
O endividamento do consumidor no cerne do capitalismo conduzido pelas finanças ${ }^{1}$
}

\author{
Robert Guttmann ${ }^{2}$ \\ Dominique Plihon ${ }^{3}$
}

Durante o verão de 2007 a crise imobiliária dos EUA transformou-se em um arrocho de crédito [credit crunch] global que está ameaçando transtornar a economia mundial. Enfrentamos hoje (meados de 2008) a perspectiva de uma desaceleração significativa ou mesmo de uma recessão global. Não importa qual desses cenários por fim se revelará, o arrocho progressivo colocou em xeque a viabilidade a longo prazo de um padrão de crescimento global que, nas últimas décadas, contou em grande medida com os Estados Unidos como o "comprador de última instância" do mundo.

Essa dramática reviravolta coloca em risco a transição suave para um novo regime de acumulação conduzido pelas finanças [finance-led accumulation regime] e para um novo padrão de crescimento multipolar. Se a crise ainda não é sistêmica, o surto atual de problemas nos principais mercados financeiros do mundo certamente sinaliza o primeiro grande teste de resistência desse novo regime. Nós gostaríamos de enfocar, nesse artigo, um pilar central do regime - o endividamento das famílias americanas - a fim de extrair algumas percepções plausíveis sobre a natureza e implicações da crise atual.

\section{Da "economia do endividamento" ao "capitalismo conduzido pelas finanças"}

Depois do colapso do padrão-ouro e do sistema bancário norte-americano no início da década de 1930, o New Deal de Roosevelt introduziu reformas monetárias - em especial o Glass-Steagall Act de 1933 e o Bank Act de 1935 que proporcionaram à economia americana uma moeda elástica e um sistema bancário seguro. O novo sistema tornou-se um pilar do boom do pós-guerra. Ao permitir a criação de moeda através da extensão do crédito, o sistema bancário ficou em posição de financiar o rápido crescimento econômico. Uma parte desse funding assumiu a forma de empréstimos bancários. Além disso, os bancos auxiliaram mais indiretamente os devedores comprando seus títulos - do tesouro, municipais ou debêntures. Não obstante esses dois canais alternativos de funding,

(1) Tradução do francês por Marcelo Freire. Revisão técnica de Fabrício Pitombo Leite.

(2) CEPN, Paris-Nord

(3) CEPN, Paris-Nord 
podemos caracterizar como economia do endividamento ${ }^{4}$ esse contínuo financiamento do gasto excedente a partir da emissão de dívida (e sua monetização automática) pelo sistema bancário.

É necessário distinguir a nossa noção de economia do endividamento da sua equivalente semântica em francês, a assim chamada économie d'endettement. Durante o boom do pós-guerra, conhecido na França como os "trinta gloriosos" (1944-1974), sistemas financeiros baseados em bancos foram um dos principais pilares do desenvolvimento econômico na Europa continental. O estreito relacionamento entre bancos e indústrias, conhecido como conexão "banqueindustrie", é considerado um dos principais fatores subjacentes ao rápido crescimento econômico europeu. As políticas públicas também desempenharam um papel ativo na formatação do sistema financeiro na Europa. Na Alemanha, assim como na França, os bancos estatais (nacionais ou regionais) atuaram como protagonistas em suas economias nacionais. As regulações foram importantes para controlar a distribuição dos empréstimos bancários e as taxas de juros. As transações no mercado de câmbio também estiveram sob rígido controle (contrôle des changes) até o final da década de 1980. A desregulação ocorreu com a constituição do mercado único europeu para serviços financeiros no início da década de 1990.

Voltando à nossa economia do endividamento do pós-guerra, a capacidade desse sistema de gerar uma oferta constante de crédito barato ajudou os governos a incorrerem em déficits orçamentários crônicos e as empresas a adotarem tecnologias de produção em massa. A extensão internacional da economia do endividamento, abordada na Conferência de Bretton Woods em 1944, permitiu que outras nações industrializadas alcançassem os Estados Unidos por meio de uma transferência sistemática de capital deste país para as primeiras durante as décadas de 1950 e 1960. As taxas de câmbio fixas de Bretton Woods complementaram um viés doméstico de baixas taxas de juros, oferecendo assim uma combinação de preços da moeda promotora do crescimento.

As políticas macroeconômicas keynesianas expansionistas puderam florescer em tal regime monetário, seja pela promoção de gastos governamentais mais elevados, pela diminuição dos impostos, pelo aumento dos gastos privados com investimento, ou por uma combinação desses. Foram fornecidos a ambos os

(4) Para uma explicação mais abrangente sobre a "economia do endividamento", ver Guttmann (1994). É preciso distinguir cuidadosamente esse conceito do seu equivalente semântico francês, "economie d'endettement" que, em reflexo à ênfase que a Europa Continental no pós-guerra deu ao "crédito administrado" rigidamente regulado, atribuindo ao estado um papel importante ao determinar a alocação e condições de crédito, enfatiza um sistema de crédito baseado em empréstimos bancários ao invés de em mercados financeiros. 
setores, púbico e privado, fundos abundantes para manter a elevação contínua nos níveis de endividamento, sustentando a aceleração dos gastos. Em tal ambiente favorável, não demorou muito para que a "economia do endividamento" se estendesse ao consumo das famílias, o maior componente de gasto da economia que absorve, tipicamente, dois terços da demanda agregada nas nações industrializadas. Como pode ser visto no Gráfico 1, a prosperidade das décadas de 1950 e 1960 revelou taxas crescentes de endividamento das famílias e das corporações. Aproveitando o declínio contínuo do ônus da dívida pública em virtude dos déficits orçamentários muitos menores que se seguiram à conversão para uma economia de paz, o uso crescente de endividamento pelo setor privado ainda deixou a razão dívida agregada/renda estável em um ambiente de rápido crescimento. Os dados mostram ainda que a dívida das famílias se elevou de uma razão de 0,37 em 1947 para mais de 0,80 no final da década de 1960, o que demonstra sua importância para o crescimento ocorrido.

Gráfico 1

Razões dívida/renda (EUA)

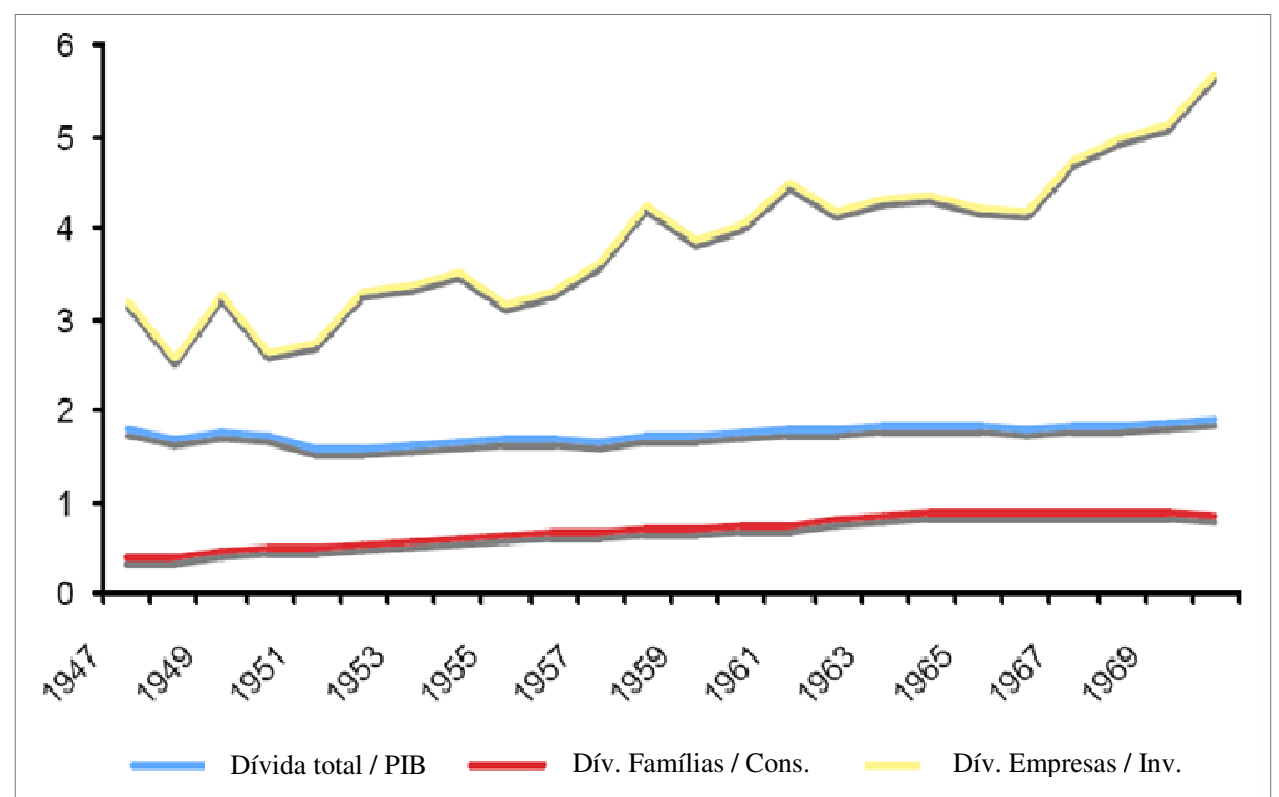

Fonte: Council of Economic Advisors (1973).

\subsection{Estagflação e a revolução da política neoliberal}

Esse cenário promissor desapareceu depois de 1969 quando a economia dos EUA enfrentou uma década de crescimento bem mais lento e de aceleração da inflação. Essa combinação, conhecida como estagflação, alimentou uma espécie 
de espiral dívida-inflação e expôs a necessidade de mudanças regulatórias abrangentes nos sistemas monetário e bancário para conseguir colocar as pressões inflacionárias sob controle no início da década de 1980 - notavelmente, um movimento em direção às taxas de câmbio flutuantes, depois de 1973, e à desregulação das taxas de juros, depois de $1979 .{ }^{5}$ Essas mudanças na determinação dos preços da moeda foram apenas os primeiros passos de uma desregulação mais ampla do sistema bancário, primeiro nos EUA (pelos Depository Institutions Deregulation and Monetary Control Act, de 1980, Depository Institutions Act, de 1982 e, finalmente, Financial Services Modernization Act, de 1999), depois também na UE (pela Second Banking Directive de 1989). Comprometidos com a mudança na política monetária para uma ênfase monetarista na estabilidade de preços, os governos dos EUA e UE tomaram uma decisão deliberada de alterar as relações de poder no sistema de crédito de um viés pró-devedor para outro pró-credor. Ao mesmo tempo, essas reformas nos sistemas monetário e bancário impuseram uma dolorosa desinflação aos devedores sobre-endividados. O vetor essencial dessa mudança, taxas de juros "reais" (i.e. ajustadas pela inflação) recordes por mais de uma década, fomentou a reestruturação industrial em escala significativa. As altas taxas de juros compeliram as empresas a tomarem decisões de investimento mais prudentes, reduziram seus horizontes de investimento (encorajando, em última instância, a ênfase na alta tecnologia e na acumulação de ativos financeiros), estimularam a gestão financeira centralizada, e colocaram mais pressão na manutenção dos custos de mão-de-obra sob controle. Mudanças institucionais nas modalidades de determinação dos salários, que culminaram no enfraquecimento dos sindicatos, dos procedimentos de negociação coletiva e das restrições à contratação e demissão nas leis trabalhistas, facilitaram para as empresas reassumir o controle dos custos de mão-de-obra e diminuir o ritmo dos aumentos salariais. Como esses esforços de reorganização tiveram o efeito desejado de eliminar as pressões inflacionárias, foi possível que as taxas de juros caíssem (no início da década de 1990) e permanecessem baixas por aproximadamente 15 anos (ver o Gráfico 2 abaixo).

(5) A segunda explosão do preço do petróleo, na esteira da Revolução Islâmica do Irã, foi parte de um conjunto mais amplo de forças perturbadoras que abalaram a economia mundial em 1979; notavelmente uma aceleração acentuada no declínio do dólar, a rápida propagação das pressões inflacionárias ao redor do globo e a reviravolta espetacular na política monetária do FED, mudando a meta das taxas de juros para o controle dos agregados monetários, o que triplicou (para mais de 20\%) as taxas de juros dos títulos denominados em dólares em poucas semanas. 
Gráfico 2

Taxas de juros nos EUA

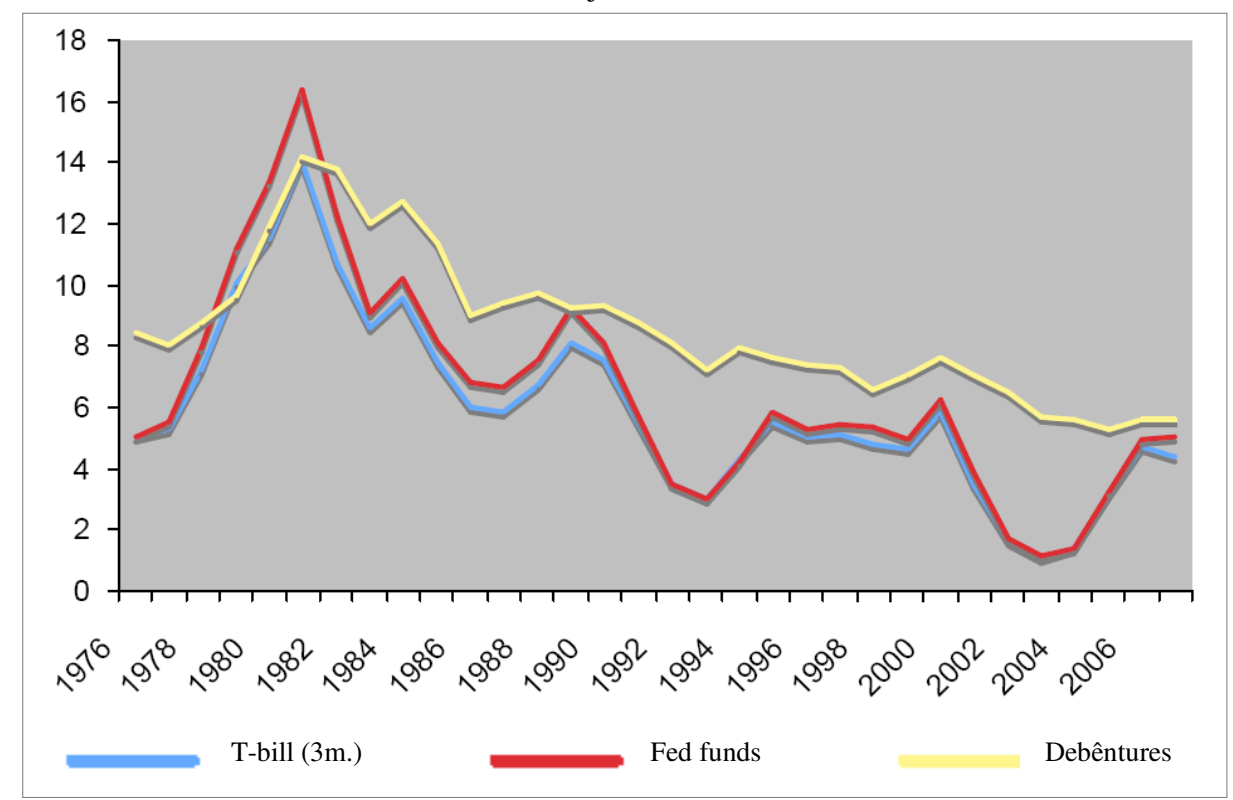

Fonte: Council of Economic Advisors (2008).

Essas mudanças pós-crise estabeleceram condições que, posteriormente, permitiriam o renascimento (e eventual extensão) da economia do endividamento nos EUA, em um ritmo ainda mais agressivo. Livres das pesadas restrições reguladoras, os bancos americanos ganharam a capacidade de definir condições de empréstimo mais favoráveis, acelerar a inovação financeira e ampliar dramaticamente o âmbito de provedores de fundos. Por fim, a desregulação fomentou a integração das atividades de banco comercial (i.e. tomar depósitos, originar empréstimos) com as de banco de investimento (i.e. organizar o mercado) em uma rede muito mais complexa de transações financeiras e contratos entrelaçados. No centro dessa rede estão os bancos transnacionais líderes do mercado mundial, que, na última década, transformaram-se em grupos financeiros multifacetados que combinam todo o espectro de atividades e serviços financeiros (e.g. de bancos comerciais e de investimento, de gestão de fundos, de seguradoras). Em oposição aos antigos "bancos universais" tão dominantes na França e Alemanha do pós-guerra, os grupos financeiros de hoje visam promover os mercados financeiros como fontes de rendimentos em vez de impedir seu desenvolvimento em favor das funções tradicionais de banco comercial. Tirando proveito da desregulação precedente e com uma maior prática na combinação de diferentes funções financeiras, os bancos europeus estiveram, por um momento, à frente de seus pares norte-americanos nessa transformação da atividade bancária. 


\subsection{O capitalismo conduzido pelas finanças e suas forças subjacentes}

Tais grupos financeiros estão no centro de um tipo qualitativamente novo de sistema econômico, que os economistas heterodoxos, particularmente os Regulacionistas franceses e os Economistas Políticos Radicais americanos, têm chamado de capitalismo conduzido pelas finanças [finance-led capitalism]. ${ }^{6}$ Diferentes características desse novo regime foram enfatizadas. Uma delas reforça a dominância de motivos financeiros, especialmente o da maximização dos valores acionários, como o objetivo primário da empresa e princípio básico da governança corporativa (Krippner, 2004; Plihon, 2004). Relacionada a isso, está a ênfase na posição estratégica dos investidores financeiros, uma classe ressurgida de rentistas alçada recentemente à dominância numa espécie de "capitalismo patrimonial" (Aglietta, 1998), e na sua capacidade de pleitear uma fatia maior da renda nacional por meio de uma variedade de fontes de rendimentos do capital, como juros, dividendos, taxas e comissões por serviços, e ganhos de capital (Epstein, 2004). Cada vez mais, economistas heterodoxos estão usando o termo "financeirização" [financialization] para realçar as diferentes dimensões da importância crescente das finanças e as implicações macroeconômicas dessa tendência (Stockhammer, 2007), muitas vezes questionada pelos seus efeitos restritivos sobre a distribuição e o crescimento (Stockhammer, 2004; Hein; Van Treeck, 2007).

A financeirização foi um processo global iniciado primeiro nos EUA e Reino Unido, no final da década de 1970, de onde se disseminou com ritmos diferentes para os outros principais países industrializados. A desregulação, a globalização e as inovações financeiras atuaram como protagonistas nesse processo de convergência global rumo ao capitalismo conduzido pelas finanças. Certamente, a França foi um dos países europeus onde as alterações foram mais rápidas e profundas. As privatizações e reformas financeiras conduzidas por sucessivos governos (inclusive os socialistas) desde meados dos anos 1980 levaram a uma rápida transição do capitalismo de estado para a inserção francesa no capitalismo global conduzido pelas finanças. Os maiores bancos e empresas franceses são de propriedade de investidores institucionais, mormente, estrangeiros (EUA). O que vemos aqui é uma dialética interessante entre uma heterogeneidade contínua resultando numa variedade de diferentes capitalismos (Amable, 2005) e uma convergência sistêmica mundial causada pela desregulação e pelo papel cada vez mais dominante das finanças.

(6) As principais contribuições da Escola de Regulação Francesa a esse respeito foram Aglietta (1998), Orlean (1999), Boyer (2000), Plihon (2004), e Coriat, Petit, e Schmeder (2006). Entre os radicais americanos que enfatizam a dominação do capitalismo contemporâneo pelo capital financeiro, observar especialmente Epstein (2004) e a edição especial vindoura da Review of Radical Political Economics sobre "A financeirização do capitalismo global: análise, criticas e alternativas", prevista para o início de 2008. 
Quaisquer que sejam as caracterizações específicas do capitalismo conduzido pelas finanças, é ponto comum que o novo regime coloca motivos, instrumentos e mercados financeiros no centro do processo de crescimento. No entanto, como permitimos que a busca por ganhos pecuniários fosse dirigida tão fortemente para os canais financeiros em vez dos comerciais ou produtivos? Em nossa opinião, há três forças inter-relacionadas por trás dessa alteração fundamental no modus operandi do capitalismo: a dependência aumentada do endividamento em todos os ramos de atividades econômicas, a facilitação de tal financiamento via endividamento pela inovação financeira, e a globalização financeira como a força mais transcendental na internacionalização do capital.

É evidente que o capitalismo contemporâneo é conduzido pelas finanças, uma vez que é, em grau sem precedentes, controlado por uma comunidade sempre crescente de investidores financeiros suprindo fundos a devedores que buscam acelerar seu crescimento por meio de endividamento adicional. Ao sinalizar o acesso a fundos de terceiros, o endividamento permite que seus usuários separem o gasto da renda e operem em uma escala maior do que fariam de outro modo. Nossa crescente dependência do financiamento via endividamento é bastante facilitada pelo ritmo acelerado da inovação financeira. Menos limitada pela tecnologia do que a inovação industrial, a inovação financeira depende mais da capacidade humana de engendrar novas promessas, torná-las reivindicações legalmente exeqüíveis de parte da receita futura de alguém e, finalmente, organizar mercados onde possam ser negociadas com ganhos. Esse tipo de atividade (planejamento e levantamento de fundos) tem baixos custos irrecuperáveis, porém, pelo mesmo motivo, pode ser facilmente copiado por outros. Seu ciclo de vida relativamente curto viabiliza tanto um ritmo acelerado quanto um viés para customização, o que torna tais inovações no sistema de crédito menos facilmente copiáveis, como está especialmente manifesto hoje nos produtos financeiros estruturados ou na gestão da riqueza privada. As principais inovações financeiras, notavelmente os derivativos (e.g. contratos futuros, opções) e produtos de securitização (e.g. títulos lastreados em hipotecas, obrigações colateralizadas por dívidas), nos levaram a empregar dez, doze, talvez quinze dólares em transações puramente financeiras para cada dólar do comércio e da produção por trás das mesmas. Essa multiplicação de registros acomoda uma ampliação igualmente impressionante da comunidade de investidores, consequiência da acumulação de riqueza por parte de mais agentes e testemunho adicional da atração irresistível que as fontes de receita financeira exercem por serem de obtenção mais fácil que os lucros industriais, aluguéis, ou quaisquer outros rendimentos provenientes da propriedade do capital. A propagação de investidores e mercados financeiros é um acontecimento global. Em relação às instalações e equipamentos usados como meios de produção ou ao trabalho, é muito mais fácil movimentar dinheiro internacionalmente. Assim, o capital 
financeiro é inerentemente a forma mais móvel de capital, especialmente quando grande parte da transferência de fundos e das atividades de negociação de títulos for movimentada on-line, no ciberespaço. A organização cada vez mais transnacional das instituições e mercados financeiros é a ponta de lança do processo de globalização mais amplo que já remodelou fundamentalmente nosso sistema econômico.

\section{A macrodinâmica do financiamento da dívida}

O capitalismo conduzido pelas finanças possui uma dinâmica própria de acumulação, seu padrão específico de crescimento. Normalmente, usamos o arcabouço keynesiano de oferta e demanda agregadas, especialmente sua variante IS/LM, para prover uma estrutura multissetorial dos usos e fontes de fundos, como no caso da análise do fluxo de fundos do FED. Pós-keynesianos trabalhando em conjunto no Levy Institute, como Godley (2002), Godley; Izurieta e Zezza (2004), ou Godley; Papadimitriou; Hannsgen e Zezza (2007), refinaram recentemente esse arcabouço a fim de realçar os principais (des)equilíbrios macroeconômicos que atuam como pilares da nossa moderna "economia do endividamento". O argumento destes é o seguinte:

A renda nacional real (ajustada pela inflação) do país, Y, é definida como:

$$
Y=X-M+G+A
$$

Admitindo que todas as variáveis são fluxos deflacionados, $G$ representa os gastos do governo, $\mathrm{X}$ as exportações mais os rendimentos de propriedade e as transferências do exterior, e $\mathrm{M}$ as importações. Compreendendo o consumo $\mathrm{C}$ e o investimento empresarial I, a variável A representa a absorção, significando o gasto privado total. Subtraindo $\mathrm{T}$, definido como impostos e transferências governamentais, de ambos os lados e reorganizando, temos:

$$
\mathrm{Y}-\mathrm{T}=(\mathrm{X}-\mathrm{M})+(\mathrm{G}-\mathrm{T})+\mathrm{A}
$$

$$
\text { ou }
$$

$$
0=(\mathrm{X}-\mathrm{M})+(\mathrm{G}-\mathrm{T})+(\mathrm{Y}-\mathrm{A})
$$

A equação (1) descreve os três principais saldos no nível macroeconômico, i.e. o saldo fiscal do governo $(\mathrm{G}-\mathrm{T})$, o saldo externo ou em conta corrente $(\mathrm{X}-\mathrm{M})$, e a poupança líquida privada $(\mathrm{Y}-\mathrm{A})$.

Embora, em si mesmas, não passem de igualdades contábeis, essas equações carregam importantes implicações. A equação (3) nos informa que o superávit em conta corrente é identicamente igual ao saldo do orçamento governamental mais a poupança líquida privada. Cada saldo implica uma alteração equivalente numa variável de estoque. Por exemplo, um déficit em conta corrente 
implica uma alteração no estoque de ativos estrangeiros, enquanto que um déficit orçamentário implica uma alteração no estoque de dívida pública e um saldo privado implica uma alteração líquida na riqueza privada.

A análise da poupança líquida para o setor privado como um todo requer que o total seja desagregado nos setores pessoal e empresarial, visto que esses se comportam, muitas vezes, de modo totalmente diferente. A desagregação do setor privado leva a:

$$
0=(\mathrm{X}-\mathrm{M})+(\mathrm{G}-\mathrm{T})+(\mathrm{Yh}-\mathrm{C})+(\mathrm{Yb}-\mathrm{I})
$$

onde Yh é a renda disponível das famílias e $\mathrm{Yb}$ a renda do setor empresarial, de modo que $\mathrm{Y}=\mathrm{Yh}+\mathrm{Yb}$, resultando na poupança líquida pessoal ser expressa por $(\mathrm{Yh}-\mathrm{C})$ e a poupança líquida empresarial por $(\mathrm{Yb}-\mathrm{I})$. A poupança líquida pessoal implica uma alteração líquida no estoque de riqueza das famílias, e a poupança líquida do setor empresarial acompanha uma mudança líquida no estoque de riqueza do setor empresarial.

Cada um desses quatro saldos setoriais representa um fluxo que sai de circulação da economia doméstica ("vazamento"), compensado pela entrada de outro ("injeção"). Ao medir os fluxos de gastos de entrada e saída do respectivo setor, sendo postos ou retirados de circulação na economia, cada saldo avalia o efeito do setor sobre a demanda agregada. De forma simétrica, cada saldo mede a entrada e saída de fluxos financeiros na economia a partir de um setor, ajudando a esclarecer como esses afetam a riqueza agregada na economia. As desigualdades entre esses fluxos dobrados de entrada e saída definem se o setor específico contribui para a poupança líquida ou, incorrendo em gastos deficitários, se necessita captar recursos em fontes de fundos disponíveis em outros setores. Se, por exemplo, o país em questão apresenta um saldo positivo na poupança privada, pode incorrer num déficit orçamentário proporcionalmente grande e/ou num superávit em conta corrente que o tornará exportador de capital para o resto do mundo. Alternativamente, o modelo de Godley et alii nos permite especificar o que deve acontecer no resto da economia para acomodar uma mudança no saldo de um setor. Se, por exemplo, nosso país sofrer uma redução na poupança líquida pessoal, terá de aumentar a poupança líquida empresarial (talvez por um declínio do investimento, induzido por uma recessão), cortar proporcionalmente o déficit orçamentário, aumentar as importações de capital (por meio de um maior déficit em conta corrente) ou, ainda, implementar ajustes que combinem várias dessas respostas.

Apesar de ser útil para a identificação dos principais indutores macroeconômicos subjacentes a um padrão particular de crescimento de uma economia nacional, o tipo de análise apresentado aqui permanece essencialmente num arcabouço de estática comparativa. Avalia a constelação prevalecente de (des)equilíbrios em dois pontos (separados e congelados) do tempo, sem nos 
informar exatamente como caminhamos de lá para cá, ou de então para agora. Embora a soma dos quatro saldos acima deva ser zero, compensando-se mutuamente de modo completamente interdependente, cada qual é mais do que apenas um resíduo dos demais. Cada saldo tem vida própria. Quando um saldo muda, provoca a equivalência necessária com os outros três, para que permaneçam compensados, através de determinadas alterações nos níveis de variáveis macroeconômicas tais como produto real, preços, taxas de juros e taxas de câmbio. Desde que o trabalho pioneiro de Godley e Lavoie (2006) nos forneceu um conjunto completo de modelos de consistência entre fluxos e estoques (SFC [stock-flow consistent]), podemos traçar o padrão de crescimento da economia ao longo do tempo. Nesse modelo, os saldos financeiros de cada setor têm contrapartidas exatas nas alterações das variáveis de estoque, de modo que os estoques de ativos e passivos forneçam o vínculo entre os diversos períodos para o traçado preciso do tempo histórico. Uma vantagem adicional do modelo GodleyLavoie é que ele contém os fluxos do setor financeiro com relação aos outros setores e seus estoques de ativos e passivos, considerando o sistema de crédito como uma força ativa na formatação do padrão de crescimento da nossa economia.

\section{A centralidade emergente do endividamento do consumidor}

Ao examinar os quatro "macro-indutores" dos modelos pós-keynesianos, podemos perceber que, nas últimas décadas, todos eles desfrutaram de grande acesso ao financiamento através do endividamento.

\subsection{Endividamento público no contexto da revolução política neoliberal}

Por exemplo, os governos em toda parte incorreram em déficits orçamentários crônicos $(\mathrm{G}>\mathrm{T})$. Esse gasto excedente é tipicamente financiado pela emissão de títulos do tesouro e parte destes é adquirida pelo sistema bancário doméstico para a monetização parcial dessa dívida. ${ }^{7}$ Enquanto que as despesas deficitárias do governo acrescentam um estímulo estabilizador à economia e financiam muitas atividades socialmente úteis, que não podem ser adequadamente tratadas pela economia de mercado movida pelos lucros (e.g. investimento em infra-estrutura, educação, manutenção de renda para pessoas sem rendimentos regulares no mercado), o endividamento público excessivo e os níveis de monetização continuamente elevados podem alimentar pressões inflacionárias. Economias com déficits orçamentários cronicamente elevados sofreram graves crises fiscais durante a década de 1980 e início da década de 1990, quando taxas de juros reais em níveis persistentemente acima das taxas de crescimento

(7) Essa monetização ocorre independentemente da nova moeda ser criada por bancos comerciais, gastando suas reservas excedentes para comprar securities, ou pelo banco central, aumentando seu estoque de títulos do tesouro e pagando por tais aquisições através da injeção de mais reservas no sistema bancário. A compra de títulos governamentais também fornece uma injeção adicional de liquidez na economia que, desde que praticada com relativa moderação, torna a carga efetiva da dívida pública menos onerosa. 
intensificaram o ônus composto pela dívida pública acumulada anteriormente. Nos principais países industrializados do $\mathrm{G} 7$, a razão da dívida pública medida como porcentagem do PIB subiu acentuadamente de 20,5\% em 1980 para 30,8\% em 1990 e 41,9\% em 1995. Essa elevação ameaçava o controle dos déficits orçamentários devido ao rápido crescimento dos encargos dos serviços da dívida pressionando as despesas do governo, e essa ameaça foi o principal motivo pelo qual os governos tiveram de cortar gastos sociais nos anos recentes abaixo dos níveis previstos. Isso foi especialmente verdade nos Estados Unidos, nos anos 1990, durante a vigência das limitações de gastos do tipo pay-as-you-go de Clinton. Na União Européia, a pressão pela disciplina fiscal talvez tenha sido até mais severa, graças à capacidade de monetização mais restrita do Banco Central Europeu (quando comparado com o FED americano) e aos limites nos déficits orçamentários e níveis de endividamento público impostos pelo chamado Pacto de Estabilidade e Crescimento, nos 15 países integrantes da zona do euro. Os governos nas economias de mercado emergentes, em grande parte despojados, desde a grande crise de 1997-9, do acesso aos empréstimos bancários domésticos que até então estavam sob seu controle político, vêem seus limites específicos de gasto deficitário sendo atualmente determinados pela sua aceitação nos mercados internacionais de títulos, com os quais foram forçados a contar.

\subsection{Débito corporativo nos EUA e na UE}

O débito corporativo também teve ampla oportunidade de se expandir de modo estável, quer para financiar despesas com capital de giro durante períodos de lacunas no fluxo de caixa, em bases de curto prazo, quer para investimentos em larga escala na capacidade produtiva, baseados num endividamento de longo prazo. Empresas de pequeno e médio porte, que não têm capacidade de emissão de títulos nem ações, dependem inteiramente dos empréstimos bancários para a obtenção de financiamento externo. Nos últimos 15 anos, com o mercado muito mais ativo para ofertas iniciais na bolsa (IPOs) e o sucesso do lançamento de um grande mercado específico para títulos de alto rendimento, o número de empresas com condições de se autofinanciar pela emissão de securities aumentou tremendamente, tornando-as menos dependentes dos empréstimos bancários. Empresas européias, ao longo desse mesmo período, aumentaram dramaticamente a emissão de debêntures, uma das repercussões positivas do papel internacional cada vez mais crescente do $€$ e da criação gradual de um espaço financeiro único através da União Européia, como resultado do Single European Act de 1987. Nos anos 1990, e ainda mais durante a recuperação de 2002-07, os setores empresariais dos EUA e UE colheram os frutos dos seus esforços de longo alcance de reestruturação corporativa realizados na década anterior, auferindo consistentemente taxas de lucro maiores e administrando taxas de autofinanciamento dramaticamente mais adequadas. Quando empresas de grande porte persistem em contrair novas dívidas de valores expressivos, estas são para 
Robert Guttmann / Dominique Plihon

atender às demandas do mercado financeiro (e.g. recompra de ações) e melhorar o controle societário (fusões, aquisições, tentativas hostis de encampação, parcerias).

\subsection{Endividamento do consumidor e estagnação dos salários}

Evidentemente, o aumento na capacidade produtiva, que as empresas podem financiar além das receitas por meio de empréstimos bancários, debêntures e novas emissões de ações, tem que ser acompanhado pelo aumento proporcional da demanda no outro lado da equação de mercado. Enquanto esse pode advir dos próprios gastos empresariais ou dos gastos governamentais, nos parece mais verossímil, especialmente quando olhamos para isso no agregado, considerar tal impulso pelo lado da demanda como originado no consumo das famílias (que representa, na maior parte das economias, de longe o maior componente da demanda, surpreendentes $72 \%$ do PIB total nos Estados Unidos). Todavia, durante as últimas três décadas, presenciamos uma inflexível estagnação dos salários nas nações industrializadas. Essa tendência se afigurou primeiro na década de 1970, quando os salários da indústria não conseguiram acompanhar o passo da inflação galopante, foi intensificada durante a abrangente reestruturação corporativa dos anos 1980, e finalmente se estendeu ainda mais com a entrada repentina de 3 bilhões de pessoas na economia mundial em consequiência do colapso do comunismo em 1991. A erosão concomitante da parcela de rendimentos do trabalho na maioria das nações industrializadas (ver o Gráfico 3), combinada adicionalmente com a ampliação da desigualdade entre a minoria vencedora e a maioria perdedora com o processo de globalização, ameaçou a estabilidade econômica doméstica, fomentando a possibilidade de condições de superprodução que exigiam ajustes recessivos (para restabelecer o equilíbrio entre oferta e demanda).

Muitos países, especialmente as economias de mercado emergentes e aquelas potências industriais tradicionais como Japão ou Coréia do Sul, conseguiram escapar de tal desequilíbrio através de estratégias de crescimento voltadas à exportação [export-led], muitas vezes alimentadas pela manutenção de uma moeda doméstica subvalorizada por meio do controle ativo das taxas de câmbio. Obviamente, nem todos podem obter superávits em conta corrente $(\mathrm{X}>$ M). Alguns países têm de absorver todos esses produtos dos países superavitários através de déficits na sua balança comercial. Os consumidores em tais países podem, obviamente, contribuir para essa absorção mesmo por trás das rendas salariais estagnadas, poupando menos e/ou trabalhando mais (como aconteceu especialmente nos EUA e, em menor escala, também na Europa). Ao final, porém, ambas as respostas possuem limitações físicas. Nesse contexto, a facilitação dos gastos das famílias adequados, a despeito da renda estagnada, é assegurada de

modo mais efetivo pelo acesso ao endividamento do consumidor, de forma que o gasto das famílias possa ser descasado dos limites da renda. 
Gráfico 3

Declínio da parcela do trabalho na renda das principais economias industrializadas

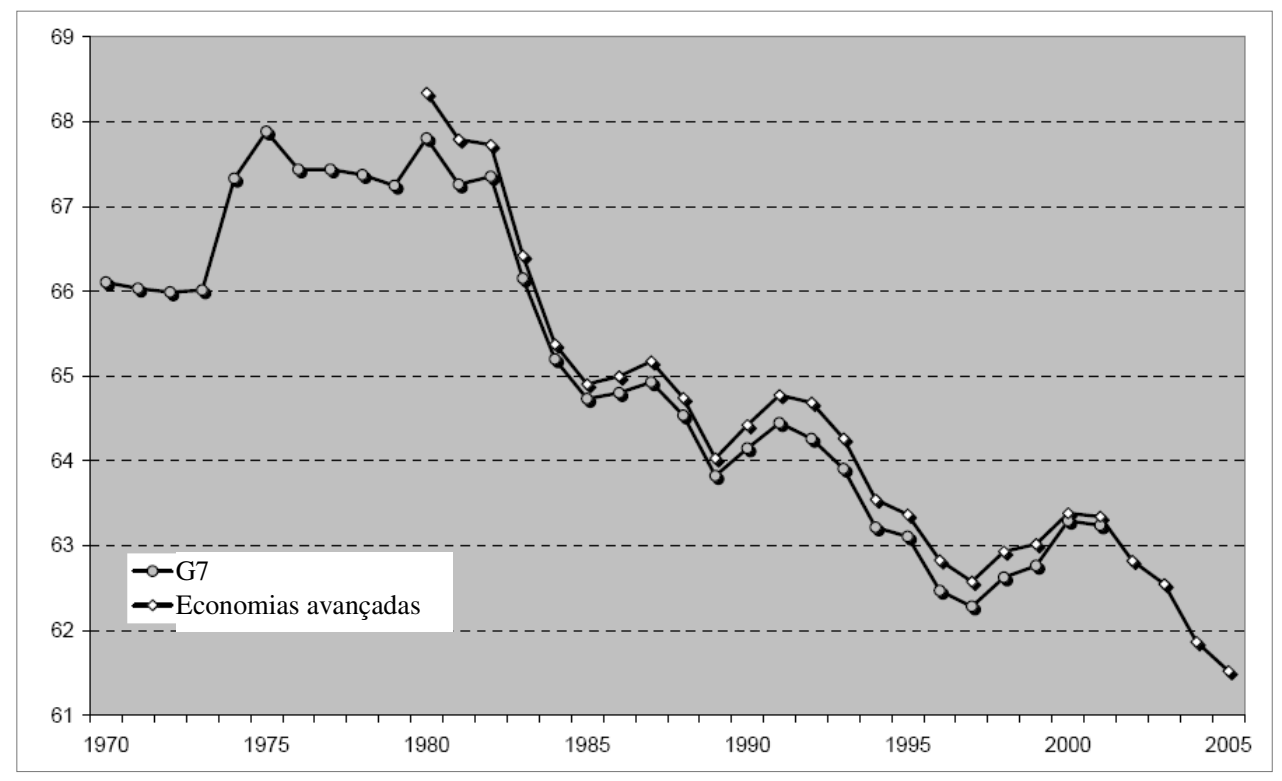

Fonte: International Monetary Fund (2007)

É possível perceber que essa tendência está se manifestando em todas as principais economias capitalistas avançadas. Em todo mundo industrializado, ao longo das últimas poucas décadas, pudemos ver a correlação entre parcelas de salários estagnadas, ou mesmo em declínio, e o crescente uso do endividamento do consumidor. Suspeitamos que possa mesmo haver uma relação simbiótica entre os dois, no sentido de que por meio da permanência do consumo impulsionado pelo endividamento em níveis suficientemente altos, o crescimento do PIB pode então ser incitado o bastante para sustentar, por sua vez, o crescente uso do endividamento pelas famílias por um longo período de tempo. A Tabela 1 mostra o aumento do endividamento do consumidor como uma porcentagem da renda disponível nos Estados Unidos e França entre 1975 e 2006. Em ambos os casos essa razão dobrou, ainda que, em um lado do Atlântico, fosse duas vezes maior do que no outro lado.

Tabela 1

Dívida das famílias como \% da renda disponível

\begin{tabular}{l|c|c}
\hline & 1975 & 2006 \\
\hline Estados Unidos & 62 & 127 \\
\hline França & 33 & 68 \\
\hline
\end{tabular}

Fonte: OCDE.

Essas constatações são adicionalmente confirmadas nos Gráficos 4A e 4B, abaixo, que representam o aumento dos níveis de endividamento dos 
consumidores em todas as nações industrializadas especificadas, enquanto apontam, ao mesmo tempo, para o nível comparativamente alto do endividamento das famílias nos Estados Unidos (ECB, 2007b). Isso suscita a pergunta sobre a razão das famílias americanas assumirem níveis significativamente mais altos de endividamento em relação a suas contrapartes na França, Alemanha ou Japão, por exemplo.

Gráfico 4A

Razão da dívida das famílias na Zona do Euro

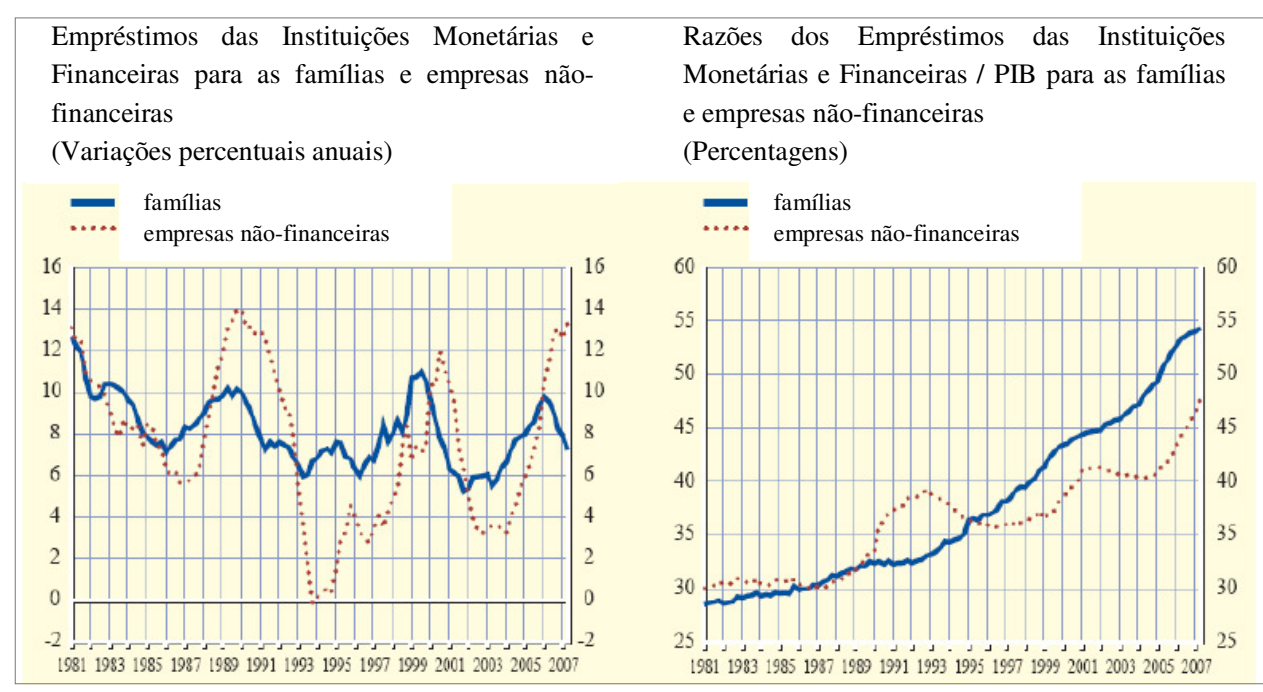

Fonte: Banco Central Europeu.

Fonte: Banco Central Europeu e Eurostat.

Gráfico 4B

Endividamento das famílias na Zona do Euro e em alguns países selecionados

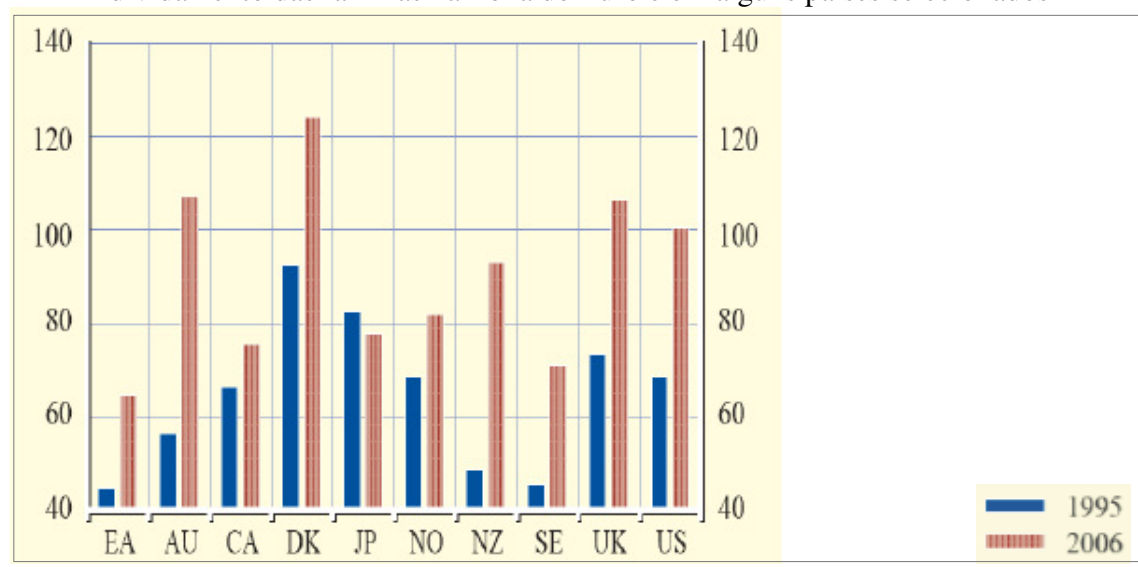

$\mathrm{EA}=Z$ ona do Euro; $\mathrm{AU}=$ Austrália; $\mathrm{CA}=$ Canadá; $\mathrm{DK}=$ Dinamarca; JP=Japão; NO=Noruega; NZ=Nova Zelândia; SE=Suécia; UK=Reino Unido; US=Estados Unidos.

Fontes: Eurostat, BIS, OCDE, e Bancos Centrais Europeu, dos EUA, do Japão, da Nova Zelândia e da Suécia. 
Um modo de responder essa pergunta é apontar para uma constelação de complementaridades institucionais nos Estados Unidos, as quais criaram conjuntamente esse viés em prol de níveis mais elevados de endividamento entre os americanos. Primeiro, há um consenso nacional, adotado rapidamente mesmo pelo mais recente imigrante almejando se integrar, sobre perseguir o Sonho Americano que, na prática, acaba sendo traduzido pela satisfação de possuir a casa própria e uma crescente capacidade de gastar. A mentalidade de enriquecimento rápido fortemente arraigada, timidamente contida pela religião organizada e/ou pelas tradições anticapitalistas encontradas aqui ou acolá, permite que o rico dite as normas sociais de consumo para o restante dos Estados Unidos. As preferências ideológicas em prol de uma estrutura reduzida de governo também levaram os norte-americanos a confiarem determinadas necessidades, que no resto do mundo são providas como bens públicos pelos próprios governos, à regulação do mercado e, por isso, eles acabaram pagando muito por coisas como educação, saúde, transporte, et cetera. Muito disso é financiado por endividamento, como os empréstimos a estudantes e os financiamentos de carros. Tais canais de empréstimos especializados amplamente disponíveis são uma expressão de um sistema de endividamento do consumidor altamente desenvolvido. Esse segmento popular do sistema de crédito dos EUA, impulsionado agressivamente pelos bancos comerciais e por prestamistas mais especializados (e.g. cooperativas de crédito, financeiras) em um ambiente muito competitivo, foi amparado por muitas décadas até agora pelo governo americano, através de uma combinação de reduções de impostos, afrouxamentos regulatórios, e de concessionários de empréstimo de responsabilidade do governo encarregados de promover seus segmentos de endividamento do consumidor (e.g. Fannie Mae e Freddie Mac para as hipotecas, e Sally Mae para os empréstimos a estudantes). Afinal, os EUA construíram toda uma economia em torno do endividamento do consumidor, incluindo agências de análise de crédito que avaliam a reputação de cada família americana, conselheiros de débitos, agências de cobrança e consultores financeiros. Os americanos têm unido cada vez mais sua propensão ao endividamento com uma baixa atenção à poupança, o perfil de preferência diametralmente oposto ao da maioria dos europeus e leste-asiáticos.

\section{Inovações financeiras e a bolha imobiliária americana}

A tendência rumo a níveis mais elevados de endividamento é estimulada por instituições financeiras procurando novos métodos para atrair mais empréstimos e realizar o funding correlato. A inovação financeira, como já mencionamos na seção 1, é um aspecto essencial do capitalismo conduzido pelas finanças. Uma força endógena dentro de qualquer sistema de crédito é iniciada pelas instituições financeiras em resposta às restrições específicas para as quais buscam novas saídas e soluções. Muitas inovações visam, por exemplo, contornar 
restrições reguladoras ou outros tipos de barreiras institucionais ao crescimento das transações financeiras. E a maior parte dessa atividade acaba facilitando a extensão de crédito dos bancos.

Esses comentários gerais também se aplicam, evidentemente, ao financiamento de consumidores. Tomemos, por exemplo, a introdução de diversas novas fontes de financiamento bancário de curto prazo no início dos anos 1960, como certificados de depósitos negociáveis (i.e. contas de depósitos de empresas que podem ser repassadas a terceiros), fundos federais (i.e. um mercado interbancário de reservas), títulos comerciais [commercial papers] (i.e. emissões de títulos de curto prazo pelas matrizes dos bancos) ou depósitos em eurodólares (i.e. depósitos a prazo denominados em dólares mantidos fora dos EUA). Os assim chamados passivos emprestáveis tornaram os bancos menos dependentes da base de depósitos tradicional para o funding dos empréstimos e, portanto, expandiram sua capacidade de emprestar muito mais agressivamente do que tinha sido o caso até o momento.

\subsection{Inovação hipotecária}

Outra onda de inovação financeira, deflagrada pela desregulação dos bancos para que competissem mais efetivamente com os rivais não-bancários menos regulados (e.g. fundos do mercado monetário, depósitos em euromoeda, financeiras, instituições de depósito), tornou possível que os bancos oferecessem toda uma nova geração de tipos de depósito (e.g. contas NOW, certificados de depósito ao consumidor, contas de depósito no mercado monetário) enquanto também renovavam radicalmente seus portfolios de produtos de empréstimos. Depois dos Deposit Institutions Deregulation and Monetary Control Act (DIDMCA), de 1980, e Depository Institutions Act, de 1982 (DIA), os bancos americanos começaram a introduzir hipotecas com taxas ajustáveis nas quais o risco de preço ficaria ao encargo do mutuário ao invés de do prestamista. Para torná-las mais apelativas, os bancos cobrariam taxas de juros artificialmente baixas no início do contrato de empréstimo, as quais seriam reajustadas para níveis mais altos posteriormente. Desse ponto, restava apenas um pequeno passo para o "balão" das hipotecas, que adiava a maioria dos encargos dos serviços da dívida para bem mais tarde, ou para os empréstimos com "amortização negativa", onde uma parte dos pagamentos de juros era incluída no principal em vez de liquidada naquele momento.

O ritmo acelerado da inovação relacionada às hipotecas levou os bancos, em meados da década de 1990, a fazerem duas alterações cruciais nos procedimentos de financiamento de imóveis. Com as taxas de juros finalmente descendo dos seus níveis elevados dos anos 1980, os banqueiros simplificaram e baratearam o refinanciamento. Foi dada a milhões de proprietários de imóveis 
americanos a oportunidade de substituírem uma hipoteca antiga antes do vencimento por outra portando taxas de juros menores e, correspondendo ao valor aumentado do imóvel servindo como garantia subjacente, também um principal maior. A outra alteração se refere à introdução dos empréstimos sobre o saldo da valorização imobiliária [home-equity loans], uma espécie de segunda hipoteca que podia ser usada para gastos de qualquer natureza, oferecendo ainda aos mutuários a vantagem de pagamentos de juros dedutíveis para fins fiscais. Ambas as inovações tornaram possível para os proprietários de imóveis americanos faturar com a valorização de seus saldos imobiliários. O início do boom imobiliário, em meados dos anos 1990, deu um estímulo extra ao consumo das famílias, o que impulsionou a economia americana para uma trajetória de crescimento maior por anos a fio. ${ }^{8}$

\subsection{Securitização}

A rápida disseminação dos refinanciamentos e empréstimos sobre o saldo da valorização imobiliária resultou em um deslocamento maciço da oferta de fundos em direção aos investimentos imobiliários, até que outra inovação financeira importante revolucionasse o financiamento da casa própria nos EUA, no início dos anos 1990. A inovação a que nos referimos é a securitização dos empréstimos, particularmente a emissão de títulos lastreados em hipotecas [mortgage-backed securities - MBS]. Esses MBS são criados quando tipos similares de hipotecas são reunidos e usados como garantia para a emissão de títulos. Os investidores em tais títulos recebem pagamentos do principal e dos juros dos empréstimos subjacentes ao pool, que são "passados adiante", menos as taxas pelos serviços e garantia. Esse re-empacotamento de empréstimos hipotecários em títulos negociáveis permitiu que os bancos recuperassem rapidamente os fundos emprestados e realizassem empréstimos adicionais, ao invés de ficarem presos a um ativo de empréstimo ilíquido por diversos anos. A rotatividade muito acelerada tornou possível aos bancos aumentar bastante o volume de empréstimos ao transferir os riscos de default para os investidores e ganhar toda sorte de taxas associadas à securitização. Lançado inicialmente no começo dos anos 1980 por entidades de responsabilidade do governo (GSE [government-sponsored entities]) como Freddie Mac, Fannie Mae e Ginnie Mae, demorou um pouco até que esse novo produto financeiro caísse no gosto popular. Em meados da década de 1990, contudo, os MBS começaram a atrair uma comunidade muito maior de investidores por causa dos rendimentos relativamente altos em um ambiente de juros baixos, especialmente quando levamos em conta a percepção amplamente difundida de seu baixo risco devido à garantia

(8) Consultar McConnell; Peach e Al-Hashimi (2003) para detalhes adicionais sobre os efeitos do refinanciamento e dos empréstimos sobre o saldo da valorização imobiliária aumentando o gasto dos consumidores e derrubando a taxa da poupança pessoal.

Economia e Sociedade, Campinas, v. 17, Número especial, p. 575-610, dez. 2008. 
governamental implícita. ${ }^{9}$ Enquanto o total de emissões anuais de MBS girou em torno de US\$ 500 bilhões durante a década de 1990, essa média triplicou para US\$ 1.500 bilhões depois de 2002 - uma cifra implicando a securitização de cerca de $80 \%$ de todas as novas hipotecas americanas nos últimos cinco anos.

\subsection{Retiradas dos saldos de valorização imobiliária}

Combinado com as baixíssimas taxas de juros mantidas pelo FED no início da década 2000, o amplo financiamento provido pela securitização de hipotecas estabeleceu um grande boom imobiliário nos Estados Unidos. Conforme o boom se firmava depois de 2002, os refinanciamentos e empréstimos sobre o saldo da valorização imobiliária permitiam que os proprietários de imóveis fizessem empréstimos com base nos valores elevados de suas residências e, desse modo, aumentassem consideravelmente sua capacidade de gastar. Correspondendo a $9 \%$ da renda disponível e figurando cerca de US\$ 840 bilhões p.a. no auge, essas retiradas aumentaram o consumo em $3 \%$ p.a. de 2002-05, equivalente a um aumento anual nos gastos de quase US\$ 300 bilhões, comparadas com 1,1\% p.a. nos anos 1990 (Greenspan; Kennedy, 2005).

Ávidas por expandir os mercados, as instituições financeiras aceleraram o boom depois de 2004 ao promoverem novos produtos hipotecários como os piggybacks, que prescindiam da exigência de entrada (efetivamente $0 \%$ de autofinanciamento), os empréstimos Alt-A, que continham maiores taxas de retorno pelo abrandamento da verificação de renda e de outras exigências de reputação quanto ao crédito, e os subprimes para mutuários com históricos de problemas de crédito. Esses empréstimos não-tradicionais eram atraentes, visto que portavam taxas muito mais altas e proporcionavam aos analistas de crédito comissões maiores. Os bancos, agora envolvidos de forma muito mais intensa na securitização de empréstimos e emitindo mais da metade de todos os novos MBS depois de 2004, empacotaram esses produtos hipotecários não-tradicionais (incluindo as chamadas hipotecas "jumbo", muito grandes para seguros da FHA) em combinações de pools de empréstimos de alto rendimento cuja securitização ainda obteria classificações de investment-grade, se mostrando assim, irresistíveis aos investidores. Esses MBS "extra-oficiais" de alto rendimento emitidos pelos bancos foram também devorados pelos investidores estrangeiros, atingindo os US\$ 500 bilhões somente em $2005 .^{10}$

(9) Em 2006, três quartos dos quase US\$ 5.000 bilhões em títulos MBS em circulação foram emitidos pelos prestamistas de responsabilidade do governo Freddie Mac ou Fannie Mae, e muitos deles portavam a garantia da Ginnie Mae ou o seguro da FHA [Federal Housing Administration]. Esses tipos de MBS contavam nesse momento com um rendimento de $1,5 \%$ a $2 \%$ acima do retorno de $4,5 \%$ auferido em uma nota do tesouro americano de 5 anos, enquanto que o MBS mais arriscado, composto por subprimes e totalmente sem seguro, podia alcançar até $15 \%$ no pico de 2006 .

(10) Ver Simon; Haggerty e Areddy (2005) para maiores detalhes. 


\section{A dinâmica do crescimento global conduzido pelos EUA e os desequilíbrios globais}

O que vemos aqui revelado é um padrão de crescimento conduzido pelo consumidor [consumer-led] nos Estados Unidos, onde o consumo das famílias compôs recentemente impressionantes $72 \%$ do PIB, bem mais alto do que em qualquer outra parte. Com a parcela dos salários e ordenados norte-americana flutuando entre 65\%-68\% durante as décadas de 1990 e 2000, tais níveis de consumo proporcionalmente altos exigiram um declínio acentuado da taxa de poupança pessoal (de uma média de $8 \%$ da renda disponível no início desse período para $2 \%$ negativos quinze anos depois, em 2006), bem como uma crescente dependência do endividamento do consumidor. Este último sofreu um aumento significativo quando os proprietários de imóveis americanos puderam tomar empréstimos maciçamente e a baixos custos diante do rápido crescimento do capital imobiliário. As retiradas sobre o saldo da valorização imobiliária proporcionaram mais da metade do crescimento nominal do PIB norte-americano durante a recuperação pós-2001. A capacidade de impulsionar o consumo financiado por endividamento, alinhada com os preços crescentes dos imóveis, tornou menos premente $\mathrm{o}$ ato de poupar. Podemos observar um declínio sustentado da poupança líquida das famílias nos Estados Unidos, desde o início dos anos 1980. Nossa hipótese é que há uma íntima relação entre o aumento do déficit em conta corrente dos EUA e a queda na poupança líquida das famílias, conforme pode ser observado no Gráfico 5.

Gráfico 5

Poupança líquida das famílias e desequilíbrios em conta corrente

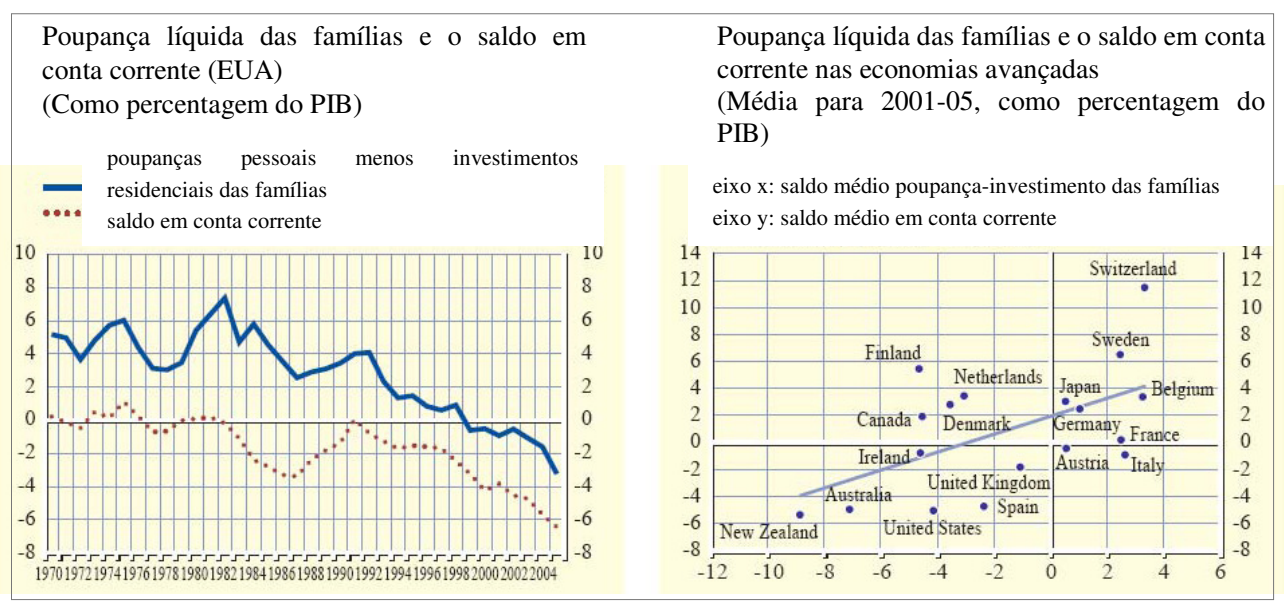

Fonte: World Economic Outlook do FMI.

Fonte: OCDE.

Embora ambos os setores, governamental e empresarial, possam contribuir para o declínio geral da poupança doméstica, parece que o papel destes tem sido 
menos preponderante no longo prazo. A evidência empírica sugere que o vínculo entre a poupança líquida das famílias e o saldo em conta corrente, mais provavelmente mediado pela evolução dos preços dos ativos (particularmente imobiliários), não se limita aos EUA, mas prevalece em vários outros países da OCDE (ECB, 2007a).

O impulso no consumo dos Estados Unidos advindo do boom imobiliário trouxe consigo importantes efeitos de transbordamento para o resto do mundo. Voltando ao modelo de Godley et alii, discutido na seção 2, a economia americana, que se deparou novamente com significativos déficits orçamentários depois de 2001, teve de compensar o crescente desequilíbrio na poupança liquida privada $(\mathrm{Yh}-\mathrm{C})$ com um déficit implacavelmente progressivo nas exportações líquidas $(\mathrm{X}<\mathrm{M})$ que, próximo a 2006, havia crescido para mais de US\$ 800 bilhões ou $7 \%$ do PIB. Em outras palavras, os Estados Unidos gastaram coletivamente $7 \%$ a mais do que ganharam em um dado período, com essa lacuna sendo amplamente financiada por importações de capital de nações que obtinham superávits constantes em suas contas correntes, notavelmente os países exportadores de petróleo da OPEP, o Japão, e as economias de mercado emergentes (EMEs), sobretudo na Ásia (i.e. China, Índia). A reciclagem desses superávits ocorreu mais ou menos automaticamente na última década, na medida em que esses países atrelaram suas moedas subvalorizadas ao dólar, o que os obrigou a comprar ativos denominados em dólares (no processo de venda de suas próprias moedas), ao protegerem suas cotações das pressões pela apreciação da moeda induzidas pelo superávit.

\subsection{O dólar americano como moeda do mundo}

Países superavitários - um agrupamento de produtores de commodities, economias de mercado emergentes, e países industrializados (ver o Gráfico 6) têm sido capazes de adotar estratégias de crescimento voltadas à exportação, baseadas em moedas deliberadamente subvalorizadas, e sustentá-las a partir do empréstimo de seus superávits ao único país apto e disposto a assumir o papel de "consumidor de última instância" do mundo. Os Estados Unidos, por sua vez, têm conseguido viver persistentemente além de seus meios com a ajuda das poupanças das nações superavitárias, acabando por absorver $75 \%$ dos desequilíbrios comerciais agregados do mundo. É digno de nota que essa relação simbiótica, subjacente à dinâmica de crescimento global das últimas poucas décadas, tem sido sustentada por uma assimetria decisiva na economia mundial, decorrente do uso da moeda nacional da potência dominante como moeda internacional nas transações entre países. Essa moeda (desde 1945, o dólar) é criada dentro do sistema bancário do país dominante e transferida por meio de fluxos contínuos líquidos de saída do país emissor para o resto do mundo. Em outras palavras, a criação da liquidez 
internacional apóia-se nos déficits constantes no balanço de pagamentos dos Estados Unidos, financiados automaticamente pelos outros países na medida em que mantêm reservas em dólar ou usam dólares na circulação internacional. Os Estados Unidos, para colocar a mesma vantagem em termos diferentes, constituem o único país capaz de tomar empréstimos externos na sua própria moeda e de fazer isso indefinidamente. São capazes, portanto, de acumular dívidas externas maiores sem sentir o mesmo tipo de carga com o serviço da dívida e, desse modo, de adotar políticas econômicas muito mais expansionistas e por muito mais tempo do que poderiam outros países. Esse afrouxamento de suas restrições externas permitiu aos Estados Unidos acumular déficits imensos em conta corrente, tê-los financiados com baixo custo pelos países superavitários, e conviver com uma taxa de poupança negativa apesar de ser o país mais rico do mundo.

\section{Gráfico 6}

Desequilíbrios em conta corrente em países e regiões selecionados Em bilhões de dólares

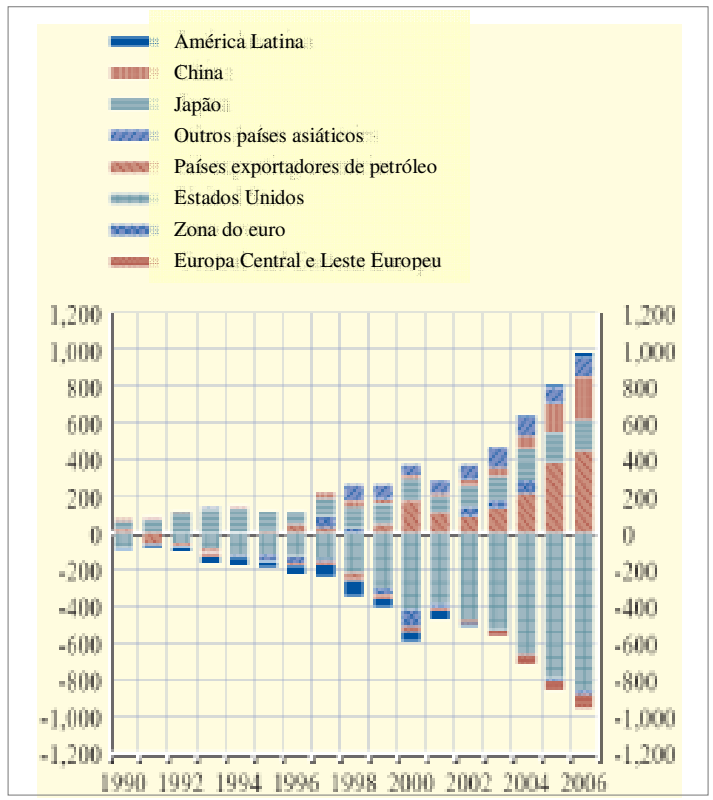

Fonte: Banco Central Europeu.

\subsection{0 excesso de poupança de Bernanke}

Ignorando a posição privilegiada dos Estados Unidos na economia mundial e o uso que tem sido feito dessa vantagem, o presidente atual do FED, Bernanke (2005), colocou a responsabilidade pela ampliação dos desequilíbrios em conta corrente diretamente nos ombros dos países em desenvolvimento. Ele alega que as crises financeiras das décadas de 1980 e 1990 reverteram o sentido 
dos fluxos de capitais, que agora fluem dos países em desenvolvimento para os industrializados. As EMEs em particular, especialmente aquelas na Ásia, aumentaram suas reservas cambiais para se protegerem de uma potencial fuga futura de capitais (ver o Gráfico 7).

Gráfico 7

Ativos de reserva internacionais

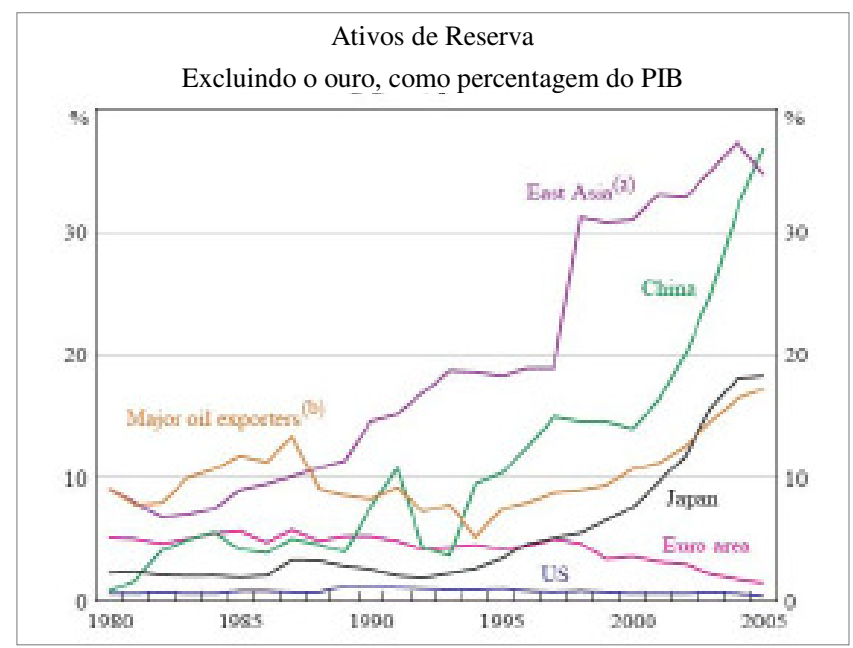

Notas: (a) Hong Kong, Indonésia, Malásia, Filipinas, Cingapura, Coréia do Sul, Tailândia e Vietnã; (b) Argélia, Irã, Kuwait, México, Nigéria, Noruega, Rússia, Arábia Saudita, Emirados Árabes Unidos e Venezuela. Fontes: FMI, IFS e Banco Mundial.

Fazendo isso, os governos dessas nações acabaram por canalizar a poupança doméstica para os mercados internacionais de capitais. Summers (2006), que foi economista chefe do Banco Mundial antes de se tornar Secretário do Tesouro do governo Clinton, observou, na mesma linha, que as reservas nos países em desenvolvimento tinham atingido um nível "muito superior a qualquer critério previamente enunciado de reservas necessárias à proteção financeira". De acordo com Bernanke, essa poupança excedente exerceu uma pressão de baixa nas taxas de juros reais, estimulando o empréstimo e, conseqüentemente, a inflação de preços dos ativos nas economias desenvolvidas. Enquanto é seguramente verdade que a manutenção de moedas subvalorizadas, por parte das EMEs, leva as mesmas a financiarem o florescente déficit em conta corrente norte-americano numa escala crescente, a hipótese de "excesso de poupança" de Bernanke, Summers, e outros influentes economistas americanos, absolve convenientemente os Estados Unidos de qualquer responsabilidade pela acumulação de grandes desequilíbrios globais. Pior ainda, esse argumento ignora inteiramente a vantagem monumental de senhoriagem auferida pelos Estados Unidos como emissor da moeda mundial. 


\subsection{Bretton Woods II?}

Uma discussão mais ponderada sobre os desequilíbrios globais correntes foi proposta por aqueles, como Bordo e Flandreau (2001) ou Dooley;FolkertsLandau e Garber (2003), que caracterizam a configuração em vigor como Bretton Woods II. Hoje em dia, como foi o caso do sistema de taxas fixas do pós-guerra, do final dos anos 1950 ao início da década de 1970, os países periféricos novamente buscam manter moedas subvalorizadas com taxas fixas para obter um crescimento por via das exportações, e, nesse processo, acabam por sustentar o déficit externo das nações centrais. Essa analogia histórica foi criticada mais recentemente por Eichengreen (2007), que destaca a importante diferença entre os superávits em conta corrente acumulados pelos EUA durante a vigência de Bretton Woods e os gigantescos déficits em conta corrente atuais. De acordo com este autor, esse déficit provém inteiramente do modo como o padrão dólar funciona atualmente, colocando os Estados Unidos como o centro ativo da economia mundial e inteiramente responsável pelos seus desequilíbrios. Sua análise oportuna termina com a pertinente questão sobre se esses desequilíbrios simbióticos podem persistir indefinidamente e, caso contrário, quais seriam os cenários de ajustamento mais prováveis. ${ }^{11}$

Qualquer eventual processo de ajuste que promovesse o realinhamento da economia mundial exigiria um aumento significativo sustentado das exportações líquidas norte-americanas ao longo dos próximos cinco anos. Desde a suspensão de Bretton Woods, realizada por Nixon em 1971, sucessivos governos norteamericanos mostraram-se propensos a deixar o dólar se depreciar a fim de impulsionar suas exportações líquidas (tornando as exportações americanas mais baratas no exterior e as importações para os Estados Unidos mais caras para seus cidadãos). O problema com esse tipo de ajuste é que, com movimentações de preços mais rápidas do que alterações de volume, qualquer depreciação aumenta inicialmente a conta das importações e, portanto, piora o déficit comercial antes de melhorá-lo (a assim chamada curva J). Além da reação defasada, há também o problema, que já se manifestou violentamente uma vez em outubro de 1979, de uma desvalorização excessivamente grande do dólar tornar-se retro-alimentadora ao ponto de colocar seriamente em risco o status do dólar como moeda mundial, justo agora que está enfrentando pela primeira vez, com a emergência do euro em 2002, um rival de peso. Essa crise pode tornar impossível para os Estados Unidos cobrirem seus déficits gêmeos ou, pelo menos, exigir taxas de juros americanas muito mais elevadas para manter os investidores estrangeiros atraídos.

(11) Essa questão também chegou a preocupar os economistas pós-keynesianos reunidos em torno de Wynne Godley no Levy Institute (www.levy.org), e C. Fred Bergsten no Peterson Institute for International Economics (www.iie.com). Ver também o interessante relatório do Banco Central Europeu (2007a) sobre essa questão.

Economia e Sociedade, Campinas, v. 17, Número especial, p. 575-610, dez. 2008. 
Certamente, os Estados Unidos ainda têm alguns atributos inerentes para evitar tais consequiências potencialmente desastrosas. Ainda é, apesar de tudo, a maior economia do mundo e, ademais, muito flexível e competitiva nesse contexto. A desvalorização significativa do dólar dos últimos poucos anos tem também tornado seus produtos muito competitivos em preço nos mercados globais. Seria melhor, evidentemente, se a maior parte desse realinhamento dos preços das moedas também envolvesse as moedas asiáticas com taxas fixas que necessitam de uma valorização significativa (iuan, iene, won, rial, etc.), seguido de um incentivo a níveis mais altos de consumo doméstico em tais economias de mercado emergentes. Além do mais, a economia dos EUA possui duas vantagens comparativas adicionais que impedem que seus déficits em conta corrente fiquem fora de controle. Uma delas é a forte presença americana na maioria dos setores de serviços, a ponto de incorrerem em superávits constantes nesse item do balanço de pagamentos, no momento em que o comércio de serviços está explodindo. Outra vantagem é o fato de que, apesar de terem acumulado uma imensa dívida externa que superou US\$ 3.000 bilhões nas últimas poucas décadas, a renda de investimentos líquida na conta corrente norte-americana é essencialmente equilibrada, o que implica taxas de retorno sobre investimentos americanos no exterior muito mais altas do que as auferidas pelos estrangeiros em seus investimentos nos EUA. ${ }^{12}$

\section{0 arrocho de crédito global iniciado em 2007}

Visto que os Estados Unidos não tiveram que enfrentar uma restrição externa como os demais países e as EMEs não têm nenhum interesse em permitir que suas moedas se apreciem muito, ou desacelerariam o ritmo tórrido de sua expansão, tem-se permitido que os desequilíbrios globais persistam e evoluam até o ponto de deflagrarem condições críticas de crise global. Depois de um período de dois anos de aperto persistente por parte do FED entre 2004-06 (i.e. dezessete altas de juros consecutivas), a bolha imobiliária americana estourou durante a segunda metade de 2006, quando as vendas, a construção, e mesmo os preços dos imóveis começaram a cair. Nesse ponto, hipotecas não-tradicionais, especialmente subprimes, começaram a ver suas "sedutoras taxas" inicialmente baixas (de 1,5\% a $3 \%$ ) sofrerem reajustes para níveis bem mais elevados (normalmente entre $10 \%$ e $15 \%$, mas atingindo $18 \%$ em alguns casos), o que fez com que muitos daqueles mutuários de risco mais alto enfrentassem, imediatamente, sérios problemas com o serviço da dívida. Na primavera de 2007 ficou claro que até um terço de todas as

(12) Esse diferencial investimento-retorno, que vai evidentemente muito além das diferenças óbvias na composição dos direitos e obrigações na conta de capitais dos EUA (e.g. aquisições estrangeiras proporcionalmente maiores de títulos do tesouro de baixo rendimento, mais investimento direto estrangeiro das multinacionais americanas em outros países), tem sido objeto de muita discussão nos últimos anos. Ver, por exemplo, Bank for International Settlements (2007) ou Curcuru; Dvorak e Warnock (2007). 
hipotecas subprime poderiam acabar em default, uma vez que os reajustes programados das taxas de juros estivessem sendo concluídos em meados de 2009, deflagrando, nesse processo, talvez até 5 milhões de execuções hipotecárias e, assim, assegurando um aprofundamento continuado do declínio no mercado imobiliário por, pelo menos, dois anos. Essa dura constatação colocou em xeque as classificações de investment-grade de um grande número de MBS que continham subprimes em seus pools. Em conseqüência disso, as agências de classificação, sob a pressão de reconhecerem seu erro, começaram a rebaixar a classificação de muitos MBS para nível inferior ao investment-grade, o que os desqualificava para a aquisição ou retenção por parte dos fundos mútuos ou de pensão.

\subsection{A crise dos subprime}

Em agosto de 2007, essa situação em deterioração explodiu repentinamente em um arrocho de crédito global plenamente maturado. Uma vez que o pico de defaults dos subprime começou a transbordar para o mercado de MBS, foi propagado o sentimento de pânico para várias outras camadas de securitização. O próximo mercado a entrar em colapso foi o de obrigações colateralizadas por dívidas (CDOs [collateralized debt obligations]), que colocava lado a lado diferentes tipos de dívidas, incluindo debêntures, títulos lastreados em hipotecas, e dívidas de cartão de crédito. $^{13}$ Um número de investidores pesadamente envolvidos com o mercado de CDOs agora paralisado, em especial fundos hedge, fundos private-equity, veículos de investimento estruturados, e outras entidades de propósito específico gerenciadas pelos bancos que estavam sendo mantidas fora dos registros, repentinamente percebeu que não tinha mais acesso aos fundos de curto prazo mobilizados pela emissão de títulos comerciais lastreados em ativos (ABCP [asset-backed commercial paper]), a terceira camada de securitização a entrar em colapso no outono de 2007. Isso os obrigou a sacar maciçamente a partir de empréstimos bancários de emergência reservados precisamente para essas eventualidades. $\mathrm{O}$ aumento inesperado na demanda por tais fundos colocou muita pressão sobre o mercado interbancário, à qual os bancos, agora subitamente apreensivos quanto às perdas prospectivas, não estavam propensos nem aptos a responder expressivamente. Como mesmo as taxas interbancárias de prazo mais curto ("overnight") moveram-se rapidamente para

(13) Esses pacotes são então divididos em fatias [tranches] que representam graus variados de risco de default e diferentes classificações correspondentes, as quais, quando vendidas como títulos, também portam retornos maiores ou menores. Esses "produtos financeiros estruturados" concederam aos investidores uma grande possibilidade de escolha sobre como gerenciar suas preferências de comparação entre risco e retorno. O problema nessa crise tem sido que os investidores, uma vez atingidos pelo pânico e prevendo o pior, têm evitado todas as fatias de CDOs, mesmo as classificadas como supostamente à prova de falhas. Para mais sobre o colapso das diversas camadas de securitização, ver Guttmann (2007).

Economia e Sociedade, Campinas, v. 17, Número especial, p. 575-610, dez. 2008. 
muito acima das metas do banco central, uma vez que a demanda por fundos começou a superar a oferta consistentemente, os principais bancos centrais do mundo tiveram que intervir repetidamente com grandes injeções de liquidez para impedir que o mercado interbancário, o centro nervoso da economia global, ficasse paralisado.

\subsection{Arrocho de crédito global}

Estamos agora no meio de um arrocho de crédito global nunca visto. As intervenções coordenadas e sem precedentes como emprestadores de última instância, do ECB, FED, Banco da Inglaterra, e outras autoridades monetárias, impediram até agora a estagnação do mercado interbancário. No entanto, essa assistência nada fez senão reanimar um sistema bancário alternativo, edificado sobre diversas camadas interdependentes de securitização, que havia entrado em colapso. Nos poucos anos subseqüentes, os bancos se depararão com centenas de bilhões de dólares em perdas com a reavaliação dos preços dos ativos, sendo que algumas delas já começaram a ser reconhecidas. E esse pesado golpe em seus lucros líquidos e níveis de capitalização os tornará bem menos propensos e aptos a conceder empréstimos em níveis adequados. O golpe mais duro atingiu os Estados Unidos, onde a crise imobiliária e o arrocho de crédito em câmara lenta estão interagindo para levar a economia doméstica americana à recessão. Evidentemente, em vista do papel dominante dos americanos como "consumidores de última instância”, qualquer desaceleração na economia dos EUA prejudicará

também diversas outras regiões. É possível que as EMEs façam uma condução voltada a uma maior dependência de seus crescentes mercados internos, alimentada por níveis maiores de consumo doméstico, ou aumentem o comércio entre elas. Também é possível que a União Européia esteja pronta para assumir o papel de locomotiva da economia mundial, desafiando os Estados Unidos pelo status de superpotência econômica.

Ainda que essas ou outras forças de realinhamento ajudem a evitar o pior, elas não podem avançar rápido o bastante para neutralizar os velozes efeitos em cascata da explosão da bolha imobiliária americana ou do colapso da securitização. O processo de ajuste necessário para corrigir os desequilíbrios globais será agora imposto um tanto brutalmente por um arrocho de crédito global, restringindo acentuadamente a capacidade americana de consumo excedente.

\section{Capitalismo de crise em crise}

O processo contemporâneo de globalização financeira conheceu três fases distintas ao longo das últimas três décadas. Cada uma delas foi impulsionada por grandes inovações financeiras e terminou numa grave crise. A primeira fase, iniciada na década de 1960 e intensificada durante os anos 1970, foi aquela do 
mercado de euromoeda. Ela terminou com a crise da dívida dos países subdesenvolvidos, de 1982-89, durante a qual mais de cinqüenta países em desenvolvimento enfrentaram defaults de-facto nos seus empréstimos soberanos nesse mercado. A segunda fase foi deflagrada pela generalização da liberalização financeira ao redor do globo, de norte a sul, durante os anos 1980 (representando também uma conseqüência da crise da dívida dos subdesenvolvidos). Esse processo corresponde a uma grande inovação financeira (Boyer, Dehove, Plihon, 2004), que terminou com as recorrentes graves crises financeiras entre as economias de mercado emergentes durante a década de 1990 (México em 1994, Leste Asiático em 1997, Rússia em 1998, Brasil em 1999, Argentina em 2001). Estamos agora, no início de 2008, no final da terceira fase, cujas consequiências não estão ainda claras, com a sua mais aguda manifestação nos Estados Unidos, onde a grande inovação da securitização impulsionou uma "economia do endividamento do consumidor" que, por fim, se degenerou, durante o verão de 2007, na crise dos "subprime".

\subsection{Três fases com crises causadas por inovações}

Fase I - Os eurodólares e a crise da dívida dos países subdesenvolvidos: O mercado de eurodólares é uma das principais inovações financeiras do século XX. Essa rede bancária global, envolvendo empréstimos e depósitos denominados em dólares fora dos Estados Unidos, floresceu em resposta a uma necessidade de liquidez monetária internacional que o sistema bancário dos EUA por si só não podia mais suprir, apesar do contínuo crescimento dos déficits norte-americanos no balanço de pagamentos. Os dois choques no preço do petróleo da década de 1970 sinalizaram dramaticamente o papel dos chamados "petrodólares", os lucros da OPEP que os bancos da City de Londres, eficientemente, passaram a reciclar a partir dos países produtores para os importadores de petróleo, ajudando assim a conter declínios globais subseqüentes. Esses "eurobancos" ajudaram a mobilizar dessa maneira uma importantíssima transferência de poupança, principalmente de Sul a Sul, por meio de operações bancárias comerciais ao invés de subsídios (como ocorrera no Plano Marshall). Contudo, esse novo sistema financeiro internacional estava sujeito a dois grandes empecilhos. Um era o escopo inadequado da regulação prudencial dos mercados de euromoeda. $\mathrm{O}$ outro era o fato de que a evolução desses mercados dependia, em última instância, fundamentalmente do andamento da política monetária dos EUA, cujos objetivos eram primariamente orientados para as condições internas americanas. Quando Paul Volcker enrijeceu a postura política do FED para encarar as pressões inflacionárias decorrentes do segundo choque do petróleo de 1979, a alta nas taxas de juros americanas e a subsequiente apreciação do dólar provocada por essa mudança de política, deflagrou, em 1982, sérios problemas com o serviço da dívida entre a maioria dos países em desenvolvimento que havia contraído 
empréstimos no euromercado, denominados em dólares, no decurso da reciclagem de petrodólares.

Fase II - Liberalização financeira e crises dos mercados emergentes: A fim de superarem suas crises de estagflação dos anos 1970, as principais nações industrializadas decidiram, sob a liderança determinada de Reagan e Thatcher, adotar as chamadas políticas do lado da oferta com base em significativas reduções de impostos para as empresas e os ricos, bem como na desregulação dos mercados de capitais e de trabalho. A União Européia tomou o mesmo rumo em 1987 com o seu projeto de "mercado único" de bens, pessoas e capitais. Nos anos 1990, esse estímulo ao livre mercado se estendeu aos países em desenvolvimento sob os auspícios do FMI, que administrou a crise da dívida dos países subdesenvolvidos impondo, aos devedores que precisavam de ajuda, programas de ajustes estruturais baseados no mantra "desregulação, privatização, estabilização" do assim chamado Consenso de Washington. ${ }^{14}$ Desse modo, foi criada uma nova categoria de países chamada de economias "de mercado emergentes", no sentido de terem sido recentemente abertas para o mercado financeiro internacional. Inicialmente, fluxos maciços de capitais para esses países ajudaram seu desenvolvimento financeiro e econômico. Logo, porém, tais políticas de livre mercado revelaram seus efeitos perversos. No nível microeconômico, os bancos das EMEs acabaram se tornando mais frágeis no rastro da sua abertura internacional. Seus balanços patrimoniais tornaram-se desestabilizados devido às operações cambiais que resultaram num perigoso descasamento de moedas [currency mismatch], à medida que passivos de curto prazo em dólares e outras moedas chave eram acumulados para financiar a criação de moeda doméstica dirigida para ativos de longo prazo denominados em moeda local, o que logo acabou por alimentar bolhas especulativas de ativos e pressões inflacionárias internas. No nível macroeconômico, as moedas locais das EMEs sofreram pressões de apreciação que, junto com as crescentes pressões inflacionárias, colocaram em risco sua competitividade e posição externa.

A deterioração das condições econômicas e financeiras colocou a maioria dos mercados emergentes, um após o outro - do México em 1994 à Argentina em 2001 - em devastadoras crises financeiras "gêmeas", que afetaram seus sistemas bancários e forçaram ajustes radicais nos regimes de taxas de câmbio. Essas crises foram o resultado da liberalização financeira excessivamente rápida e mal administrada para a qual esses países estavam precariamente preparados. Nem as organizações internacionais, notavelmente o FMI, nem os governos

(14) O "Consenso de Washington" se reporta às tendências da política de livre mercado da Casa Branca de Reagan, do Fundo Monetário Internacional, e do Banco Mundial, todos com sede em Washington, D.C. Para uma boa crítica desse viés ideológico desbalanceado exclusivamente a favor das soluções de livre mercado, ver Stiglitz (2002). 
compreenderam que o processo de liberalização financeira constituía uma grande inovação financeira que produziria frutos positivos apenas em um contexto institucional corretamente adaptado (Boyer; Dehove; Plihon, 2004). Na maioria das EMEs, este estava longe de ser o caso.

Fase III - Endividamento do consumidor, securitização e a crise dos subprime: A securitização de empréstimos é uma importante inovação financeira que, como no caso dos mercados de eurodólares algumas décadas antes, introduziu uma nova forma de intermediação financeira. É uma atividade especialmente bem adaptada às operações de empréstimo padronizadas de grandes volumes, especialmente aquelas relacionadas ao endividamento das famílias. A securitização é um instrumento eficiente de transferência de risco, do mesmo grupo dos derivativos. Todavia, como as demais inovações financeiras, apresenta efeitos ambivalentes, bons e maus. Projetada para melhorar a gestão de riscos, a securitização, na verdade, acaba estimulando os bancos a assumirem muitos riscos, na medida em que sabem que é possível transferi-los para terceiros (i.e. risco moral). Nesse sentido, a securitização tornou-se vítima do seu próprio sucesso. Por um lado, ao simplificar o financiamento das famílias, alimentou o acúmulo (excessivamente) rápido de dívidas entre estas. Por outro lado, por incentivar a dispersão dos riscos, contribuiu para a diluição da responsabilidade ao longo da cadeia de gestão de riscos, agravada pela natureza obscura dos mercados de balcão nos quais os produtos securitizados são normalmente negociados. Por isso, como instrumento de transferência de risco, a securitização provou ser um poderoso vetor na propagação internacional da crise. Nesse sentido, é justo questionar se a crise dos subprime não é basicamente o resultado dos efeitos perversos da securitização. Sua extensão e intensidade totalmente surpreendentes podem ser explicadas pelo fato de que essa crise atinge, ao mesmo tempo, as raízes profundas do capital financeiro e a sociedade americana do endividamento do consumidor.

A crise atual dos subprime pode ser classificada como uma crise sistêmica na medida em que atinge três pilares fundamentais do capitalismo conduzido pelas finanças: um padrão de crescimento global centrado nos EUA, carente de diversificação para pólos alternativos de crescimento; o paradigma das finanças modernas, que enfatiza a gestão de riscos; e a pretensa estabilização do padrão de crescimento outrora cíclico.

\subsection{O padrão de crescimento global}

Até agora, a economia dos EUA tem desempenhado o papel de "consumidora de última instância" do resto do mundo, servindo, desse modo, como uma locomotiva que arrasta, para o seu imenso mercado interno, diversas outras economias extremamente dependentes de exportação. Têm ocorrido efeitos de transbordamento importantes da economia americana para outras partes do 
mundo (Europa, Japão, América Latina, Leste Asiático), confirmando o ditado de que "se a economia dos EUA espirrar, o resto do mundo fica resfriado". Como já ressaltamos, em vista do papel dominante dos americanos como "consumidores de última instância", qualquer desaceleração na economia dos EUA pode prejudicar também diversas outras regiões.

Ao mesmo tempo, contudo, há indicações de que o padrão de crescimento global pode estar mudando (IMF, 2007). A recente desaceleração na economia norte-americana ainda não apresentou qualquer efeito significativo em outras economias, o que sugere que pode estar havendo algum "desacoplamento" entre o resto do mundo e os Estados Unidos. A economia dos EUA totaliza cerca de 20\% do PIB global, quando calculado com base na paridade do poder de compra, comparada a uma parcela de $25 \%$ das cinco maiores economias de mercado emergentes. Certamente, há indicações de que o resto do mundo está se tornando menos dependente da economia dos EUA a longo prazo, não devendo ser desconsiderada a importância crescente da integração regional na Europa, Ásia e América Latina. No longo prazo, estamos gradualmente nos movendo em direção a um padrão de crescimento global multipolar, levado adiante pelo aprofundamento da integração regional. No entanto, como assinalado acima, ao passo que essas (ou outras) forças de realinhamento podem ajudar a evitar o pior no curto prazo, provavelmente não avançarão rápido o bastante para neutralizar os velozes efeitos em cascata da explosão da bolha imobiliária americana ou do colapso da securitização.

\subsection{O paradigma da gestão de riscos das finanças modernas}

A crise dos subprime revelou que as finanças modernas não são mais capazes de cumprir com uma das suas funções essenciais, a da gestão dos riscos. E nesse sentido essa é uma crise profunda, que afeta sobremaneira todos os atores das finanças internacionais: banqueiros, investidores, agências de classificação, bancos centrais, reguladores bancários.

- A securitização e os derivativos privaram os bancos da sua função tradicional como intermediários financeiros e os transformaram em corretores de mercados financeiros. Dessa forma, os bancos não mais carregam eles mesmos os riscos, mas os transferem para os mercados financeiros - uma tendência ainda mais acentuada pelo novo regime regulatório para os bancos, conhecido como Basiléia II. ${ }^{15}$ Sabendo que revenderão grande parte dos seus ativos, os bancos não estão mais preocupados com a avaliação correta dos riscos, os quais esperam ser

(15) O assim chamado "Basiléia II", uma revisão do Acordo de Basiléia de 1988 atualmente em implementação sob os auspícios do Bank for International Settlements (BIS), permite que os bancos ao redor do

globo determinem seus próprios níveis de capitalização em função do êxito que obtêm ao calcular e gerenciar seus riscos (de crédito, de mercado, operacionais e outros). 
assumidos por terceiros. Isso provoca a erosão gradual da qualidade dos riscos, uma inclinação para subestimar riscos na busca por maiores retornos.

- Os bancos de investimento encarregados da securitização combinam todos os tipos de empréstimos nos pools a serem securitizados, o que dificulta a avaliação adequada do risco. Adicionalmente a isso, há a proliferação de técnicas de transferência de risco especialmente obscuras em mercados de balcão nãoregulados (e.g. derivativos de crédito, garantias de passivos contingentes), o que deixa todos os tipos de atores financeiros mais vulneráveis à medida que assumem riscos ocultos, desconhecidos para eles.

- Nesse novo contexto, as instituições financeiras não querem assumir os riscos de crédito e de mercado dos seus compromissos, mas, em vez disso, preferem transferi-los por todo o percurso até o poupador final - uma tendência que explica a construção de várias camadas de securitização, onde os produtos securitizados são combinados em pools para ulterior securitização. Nesse ponto, o sistema financeiro não desempenha mais seu papel primordial de avaliação e gestão dos riscos.

- As agências de classificação (Moody's, Standard \& Poor's, etc.) também pararam de fazer apropriadamente seu trabalho de avaliação da reputação de crédito dos mutuários, uma vez que acreditam que todos os empréstimos podem ser transformados em títulos e vendidos a investidores.

- E no meio de todas essas falhas sistêmicas da gestão apropriada de riscos, os bancos centrais se viram obrigados a socorrer bancos passando por sérias dificuldades. Eles tiveram de intervir, com receio de que uma crise de confiança no mercado interbancário desencadeasse uma crise sistêmica que paralisasse o sistema de crédito. Embora os bancos centrais estejam totalmente cientes de que tais operações de salvamento induzem os bancos a ignorar ou dar menos atenção ao nível de risco dos seus compromissos (o problema do risco moral), eles não podem arcar com as conseqüências de não intervir. Ao injetar quantidades maciças de liquidez no sistema bancário hoje, o banco central pode estar pavimentando o caminho para mais uma crise financeira amanhã.

\subsection{Fragilidade financeira de Minsky}

O capitalismo conduzido pelas finanças, com sua ampla provisão de crédito a baixas taxas de juros, tem a vantagem de separar os gastos da renda. Essa separação permite que a demanda agregada seja mantida em níveis suficientemente altos para evitar ajustes recessivos. Desde o último declínio importante no início dos anos 1980, a economia mundial, notavelmente a americana como sua principal componente, enfrentou apenas dois declínios relativamente superficiais e de curta duração (1990-1991, 2000-2001). Ambos 
foram superados com relativa rapidez devido à atuação agressiva da política monetária, empurrando as taxas de juros para baixo; à elevação acentuada dos déficits orçamentários, aumentando os gastos; e às fontes ininterruptas de crédito, sustentando os gastos do setor privado a despeito da estagnação ou mesmo queda dos rendimentos.

Esses longos períodos de estabilidade, todavia, semearam as sementes de sua própria destruição ao produzirem, como H. Minsky (1964) afirmou de modo tão convincente, estruturas financeiras cada vez mais frágeis que culminariam, eventualmente, em uma grande crise. Como as unidades deficitárias de gastos (i.e. empresas, famílias) obtiveram êxito com suas ações anteriores, elas se tornaram mais propensas a assumir um risco maior em seus compromissos subseqüentes. Pode-se observar o mesmo viés entre seus prestamistas. Na ausência de qualquer ajuste recessivo significativo, os agentes econômicos deixam de perceber a possibilidade de falha. Tornam-se muito otimistas, inclinados a subestimar os riscos na busca por maiores retornos. Essa euforia é socialmente construída, logo amplamente compartilhada. Ao longo do tempo, normalmente em questão de poucas décadas ou um quarto de século sem nenhuma desaceleração importante, as posições financeiras dos devedores e credores ficarão progressivamente mais precárias em virtude de uma assunção de riscos aumentada. Nesse contexto, Minsky distinguiu entre três posições de financiamento: hedge, onde a posição líquida dos fluxos monetários dos devedores é suficientemente positiva para nunca pôr em risco o pagamento do serviço da dívida; especulativo, onde as posições líquidas dos fluxos monetários podem ser, às vezes, inadequadas para honrar os compromissos de pagamento à medida que chegam seus vencimentos; e financiamento Ponzi, quando é necessário endividamento adicional para atender aos encargos do serviço da dívida existentes. Na ausência de qualquer ajuste recessivo que elimine os devedores mais vulneráveis e relembre a todos sobre os perigos de assumir riscos excessivos, a estrutura financeira torna-se cada vez mais frágil, contendo uma proporção crescente de unidades especulativas e Ponzi nas ultimas fases de um boom prolongado. É nesse ponto que um evento (de outro modo relativamente insignificante) pode expor o grau de extensão excessivo prevalecente na estrutura financeira da economia, deflagrando uma atitude de pânico que irrompe numa reação em cadeia de defaults, vendas compulsórias de ativos, colapsos no mercado financeiro, e escassez generalizada de crédito disponível - a configuração de uma crise financeira.

Nós temos um bom motivo para nos perguntar em que medida a visão de Minsky sobre a construção da crescente fragilidade financeira durante um longo boom que perpasse vários ciclos também não se aplica à família média americana e seu imenso acúmulo de dívida sobre o consumo nos últimos 25 anos, com o estouro da bolha imobiliária servindo como catalisador de uma grande crise 
financeira em escala global. Se esse é realmente o caso, então acabamos de entrar em um processo de ajuste acionado pela crise, o qual extrapola, tanto em extensão quanto em profundidade, um mero ajuste recessivo.

\section{Conclusão: A necessidade de um arcabouço metateórico}

Estamos conscientes de que esta contribuição levanta mais questões do que respostas. Mas isso é da natureza do objeto. Estamos apenas no princípio do que parece ser uma crise sistêmica de grandes proporções e, neste momento, não temos nenhuma idéia concreta de qual será o desenrolar de toda essa história. Nossa capacidade de identificar os cenários mais prováveis no futuro próximo e de presumir o que de melhor há para se fazer a respeito depende da nossa compreensão do que está acontecendo.

Essa questão é de vital importância e exige, à luz de nossa dinâmica de crescimento globalmente integrada, um novo arcabouço analítico que trate o todo - a economia mundial - como mais do que a soma de suas partes - isto é, das cento e noventa e uma economias nacionais vinculadas entre si por meio de seus respectivos balanços de pagamentos e taxas de câmbio. Tal arcabouço terá de aguardar uma revolução metateórica, similar à revolução macroteórica de Keynes de setenta anos atrás. Na ausência da mesma, podemos somente identificar possíveis elementos centrais de tal arcabouço metateórico, com base em nossa análise apresentada acima.

Já indicamos anteriormente (na seção 2) que o modelo de consistência entre fluxos e estoques (SFC) de Godley e Lavoie pode servir como um bom ponto de partida. Refinamentos adicionais do papel que as finanças desempenham no modelo SFC deveria ser um valioso exercício com a finalidade de apreendermos um sentido ainda mais preciso da dinâmica subjacente aos processos de crescimento atuais das economias capitalistas avançadas. Mudanças em suas composições internas e/ou nos seus fluxos com outros setores acrescentam uma dimensão de injeção de liquidez com a qual o todo se torna mais do que a soma de suas partes. Em outras palavras, a criação de moeda dentro do setor financeiro permite a qualquer dos outros quatro setores separar os gastos das receitas, pelo menos por um tempo. Dado tal relaxamento das restrições monetárias financiado por crédito, qualquer um desses setores pode acumular dívidas e sustentar substanciais déficits sem deflagrar ajustamentos autocorretivos durante algum tempo. Podemos conceber os principais saldos setoriais - das empresas, das famílias, do governo, e o externo - como os quatro pilares da nossa

moderna "economia do endividamento", e o setor financeiro como o provedor dos fundos para tal gasto excedente. 
Podemos então usar o modelo SFC refinado como o ponto de partida para uma análise mais profunda do modus operandi do capitalismo conduzido pelas finanças e de como esse é movido adiante pela confluência de uma dependência ampliada do financiamento a partir do endividamento, da inovação financeira, e da globalização das instituições e mercados financeiros. A principal alteração qualitativa que caracteriza o capitalismo conduzido pelas finanças como tal, e que constitui um dos fatores de difícil integração em modelos meramente quantitativos no nível macro, é a capacidade do sistema como um todo de gerar nova liquidez, além de quaisquer dados nível e distribuição das poupanças, e ofertar essa moeda recém-criada via crédito como renda disponível antes que esta tenha sido realmente auferida. Tal criação de liquidez não é, todavia, um processo linear, mas, pelo contrário, sujeito a um ciclo de crédito constituído de recuperação, excesso, crise e reajustamento. Tanto a "hipótese da instabilidade financeira" de Minsky, ciclicamente orientada, quanto sua freqüentemente esquecida noção de uma propensão de onda mais longa rumo à fragilidade financeira supracíclica, de 1964, são úteis aqui, especialmente quando recontextualizadas como modelos de economias abertas que levam em consideração as especificidades do sistema monetário internacional prevalecente. Isso exige necessariamente um olhar mais detalhado para a estrutura complexa dos diferentes fluxos transfronteiriços de capitais. ${ }^{16}$

Tentando aplicar esses elementos conceituais de uma abordagem metateórica à dinâmica de crescimento global que está se revelando nesse momento, concluímos que a simbiose de longa data entre o consumo excedente dos EUA e o crescimento estimulado pelas exportações das EMEs está prestes a ter um fim, graças ao estouro da bolha imobiliária americana e ao colapso associado de um sistema bancário alternativo recentemente criado com base em várias camadas de securitização. Embora ainda seja muito cedo para falar aonde a crise nos levará, parece-nos que estamos presenciando uma crise sistêmica. $\mathrm{O}$ primeiro teste de resistência de um regime de acumulação qualitativamente novo pressionará os policy-makers a procurarem novas soluções de regulação e de política necessárias à estabilização do capitalismo conduzido pelas finanças.

\section{Referências}

AGLIETTA, M. Le capitalisme de demain. Paris: Fondation Saint-Simon, 1998.

2007.

; BERREBI, L. Désordres dans le capitalisme mondial. Paris: Odile Jacob,

(16) Um bom esforço de reformulação da hipótese da instabilidade financeira de Minsky em um modelo de economia aberta (nesse caso, para compreender a crise das economias de mercado emergentes de 1997-99) pode ser encontrado em Wolfson (2000). Tanto Brender e Pisani (2007) quanto Aglietta e Berrebi (2007) fornecem excelentes análises dos padrões de crescimento global, o que nos move para mais perto do arcabouço metateórico que necessitamos. 
AMABLE, B. Les cinq capitalisms: diversité des systèmes économiques et sociaux dans la mondialisation. Paris: Seuil, 2005.

BANK FOR INTERNATIONAL SETTLEMENTS. What explains the US net income balance? BIS Working Paper, n. 223, Jan. 2007.

BERNANKE, B. The global saving glut and the US current account deficit. Remarks at the Sandridge Lecture, Virginia Association of Economics, Richmond, Virginia, 10 Mar. 2005.

BORDO, M.; FLANDREAU, M. Core, periphery, exchange-rate regimes and globalization. In: BORDO, M.; TAYLOR, A.; WILLIAMSON, J. (Ed.). Globalization in historical perspective., Chicago: University of Chicago Press / National Bureau of Economic Research, 2001. p. 417-472.

BOYER, R. Is a finance-led growth regime a viable alternative to fordism ? A preliminary analysis. Economy and Society, v. 29, n. 1, Feb. 2000.

; DEHOVE, M.; PLIHON, D. Les crises financiers. Paris: La Documentation Française, 2004. (Conseil d'Analyse Economique Report, n. 50). Disponível em: www.cea.gouv.fr.

BRENDER, A.; PISANI, F. Les déséquilibres financiers internationaux. Paris: La Decouverte, 2007.

COUNCIL OF ECONOMIC ADVISORS. Economic Report of the President. Washington, DC: US Government Printing Office, 1973/2008.

CORIAT, B.; PETIT, P.; SCHMEDER, G. (Ed.). The hardship of nations: exploring the paths of modern capitalism. Aldershot, UK: E. Elgar, 2006.

CURCURU, S.; DVORAK, T.; WARNOCK, F. The stability of large external imbalances: the role of returns differentials. Washington, DC: NBER, May 2007. (NBER Working Paper, n. 13074).

DOOLEY, M.; FOLKERTS-LANDAU, D.; GARBER P. The revived Bretton Woods system. International Journal of Finance and Economics, v. 9, n.4, p. 307-313, 2003.

EICHENGREEN, B. Global imbalances and the lessons of Bretton Woods. Cambridge, MA: MIT Press, 2007.

EPSTEIN, G. (Ed.). Financialization and the world economy. Aldershot, UK: E. Elgar, 2004.

EUROPEAN CENTRAL BANK. Adjustment of global imbalances in a financially integrating world. Monthly Bulletin, p. 62-74, Aug. 2007a.

. Long-term developments in MFI loans to households in the euro area: main patterns and determinants. Monthly Bulletin, p. 69-84, Oct. $2007 \mathrm{~b}$.

GODLEY, W. Strategic prospects and policies for the U.S. economy. Annandale-uponHudson: Levy Institute, 2002. (Economics Strategic Analysis Archive, n. 02-4).

; IZURIETA, A.; ZEZZA, G. Prospects and policies for the U.S. economy: why net exports must now be the motor for U.S. growth. Annandale-upon-Hudson, NY: Levy Institute, 2004. (Economics Strategic Analysis Archive, n. 04-7). 
Robert Guttmann / Dominique Plihon

GODLEY, W.; LAVOIE, M. Monetary economics: an integrated approach to money, credit, income, production and wealth. London: Palgrave Macmillan, 2006.

; PAPADIMITRIOU, D.; HANNSGEN, G.; ZEZZA, G. The US economy - Is there a way out of the woods? Annandale-upon-Hudson, NY: Levy Institute, 2007. (Economics Strategic Analysis Archive, n. 07-11).

GREENSPAN, A.; KENNEDY, J. Estimates of home mortgage originations, repayments, and debt on one-to-four-family residences. Washington, DC: Federal Reserve Board, 2005. (Finance and Economics Discussion Series, n. 2005-41).

GUTTMANN, R. How credit-money shapes the economy: the United States in a global system. Armonk, NY: M. E. Sharpe, 1994.

The collapse of securitization: from subprimes to global credit crunch. Villetaneuse: Centre d'Economie Paris-Nord, Dec. 2007. (La Lettre du CEPN, n. 2).

HEIN, E.; VAN TREECK, T. 'Financialisation' in Kaleckian/Post-Kaleckian models of distribution and growth. Düsseldorf, Germany: Institut für Makroökonomie und Konjunkturforschung, 2007. (IMK Working Paper, n. 07-2007).

INTERNATIONAL MONETARY FUND. Spillovers in the global economy. World Economic Outlook, Apr. 2007.

KRIPPNER, G. The financialization of the US economy. Socio-Economic Review, v. 3, n. 2, p. 173-208, 2004.

MCCONNELL, M.; PEACH, R.; AL-HASHIMI, A. After the refinancing boom: will consumers scale back their spending. Current Issues in Economics and Finance, Federal Reserve Bank of New York, New York, v. 9, n. 12, p. 1-7, 2003.

MINSKY, H. Longer waves in financial relations: financial factors in the more severe depressions. American Economic Review, v. 54, n. 3, p. 324-335, 1964.

ORLEAN, A. Le pouvoir de la finance. Paris: Odile Jacob, 1999.

PLIHON, D. Le nouveau capitalisme. Paris: La Decouverte, 2004.

SIMON, R.; HAGERTY, J.; AREDDY, J. Global investors gobble up mortgage-backed securities, Keeping prices strong. Wall Street Journal, A1, Aug. 24, 2005.

STIGLITZ, J. Globalization and Its discontents. New York: W.W. Norton, 2002.

STOCKHAMMER, E. Financialisation and the slowdown of accumulation. Cambridge Journal of Economics, v. 28. n. 5, p. 719-741, 2004.

Some stylized facts on the finance-dominated accumulation regime. Paper presented at the Finance-led Capitalism? Macroeconomic Effects of Changes in the Financial System," 11th Workshop of Research Network Macroeconomic Policies, Berlin, Oct. 26-27, 2007.

SUMMERS, L. Reflections on global account imbalances and emerging market reserves. L K Jha Memorial Lecture, Reserve Bank of India, Mumbai, 24 Mar. 2006.

WOLFSON, M. Neoliberalism and international financial instability. Review of Radical Political Economics, v. 32, n. 3, p. 369-378, 2000. 